\title{
防空上より见たる電鐵の電弧について
}

\author{
照朋學會東京支部主催照叨砸究會
}

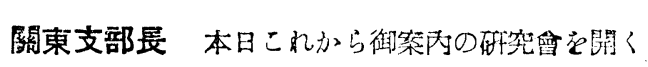
ことになりますが，今日は衔案內狀にもありますや

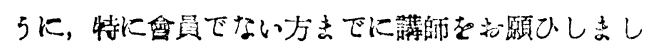

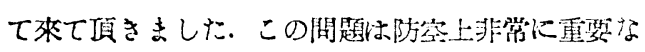
問題であるに方拘らす，照明學會では今迄一寸のん。

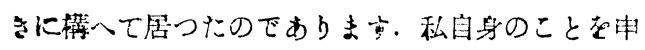

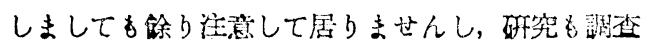
る開いたことるなかつたのであり去。今日は非常

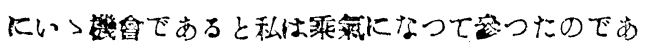

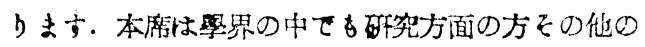

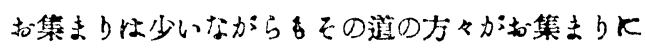
なつて居られることは心强いのでありま方がすう少

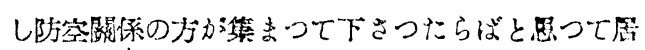
ります。或ひはこれからお篗まりになるかも知れる

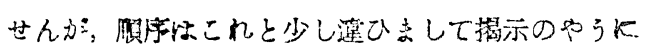

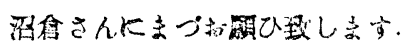

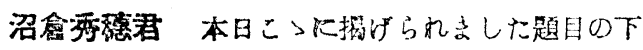

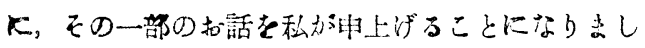

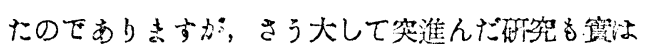
やつて居りませんので，皆さんの前で赤するとい

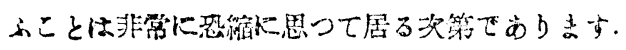

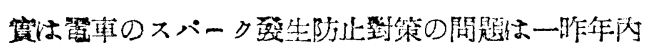

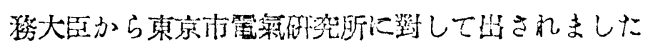

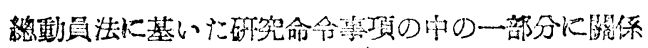
した問題でありまして，さういふ關係でこの間題の

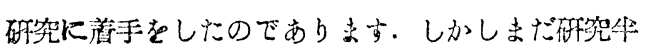

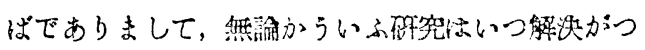
くかといふやうなことは難かしい間題ではあります

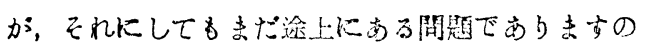

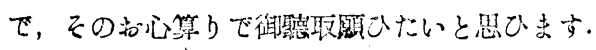

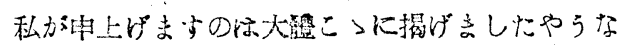
內容长從つてお話在致します。

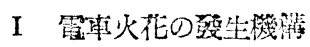

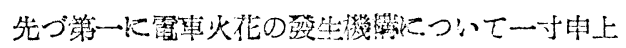

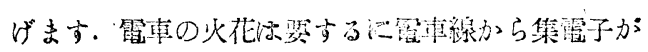

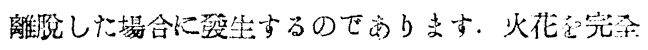

に防止しやうとすれば全然雕脱しないやうな方法を

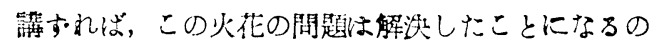

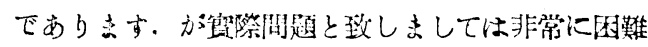
なことであります。これで色々确究が必要になつて

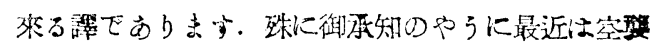

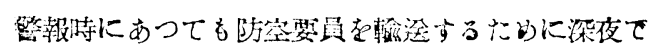

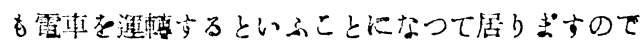

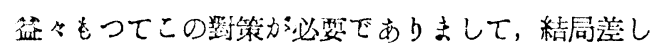

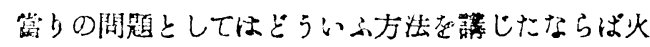

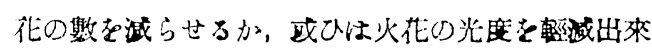
るかといふやうなこと出來るげけ解氿しなけれい゙ ならはといふ狀態にある显なのてあります。

さてこの霍植の火化と畃しますすのは即䜊スハ

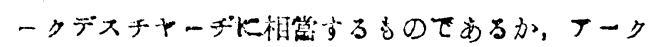
デスチヤーデに相䍃するものである水をいふことに なる琵でありますが，こ机怡兩方走含んげやうなる のだと思はれま市，がどつちかといふとアークに，

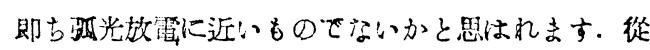

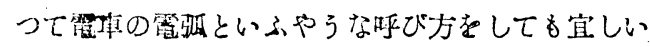

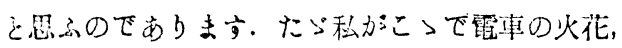

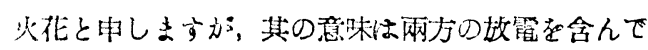

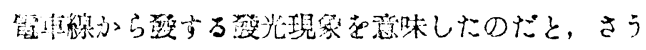

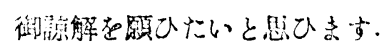

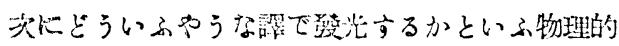

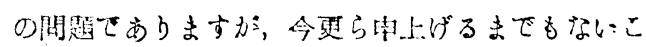

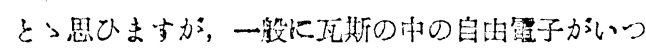
てる正イオンと䊁合する性買都持つてるるものだあ りまして、この結合した時に光り故受市ることにな

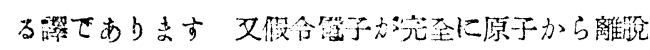

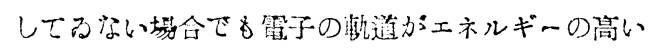

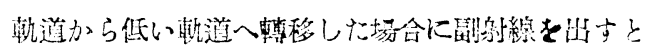

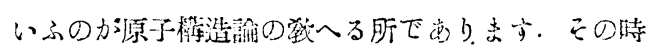

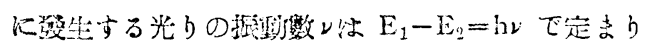
ます.始で $\mathrm{E}_{1}$ は最初の狀態のエホルギー。 $\mathrm{E}_{2}$ は後 の狱態のエネルギー．hはブランクの定鞂で 6.626×

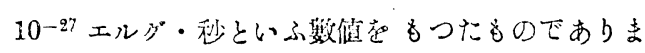

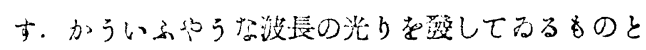


見别东古。

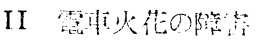

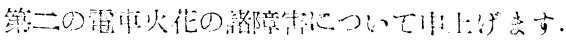

\section{(イ) 防空1:の障管}

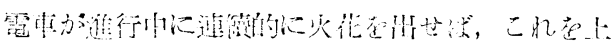

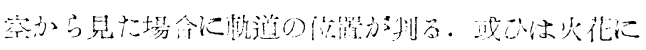

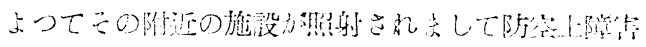

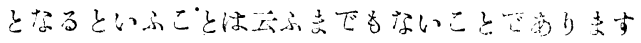

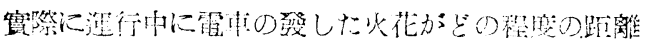

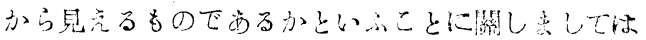

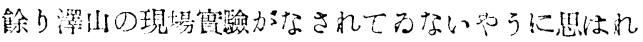
ますので，はつきりしたことは步トげられないので

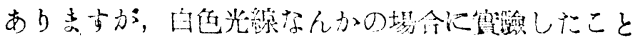

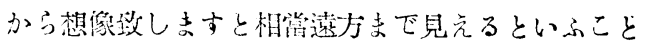
む゙老へられるのであり声す。例へば 100 獨の自色光

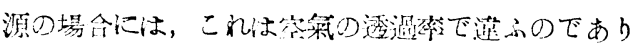

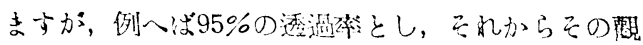

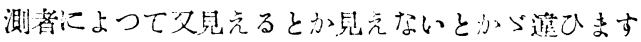

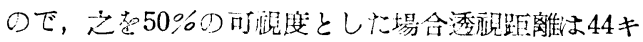

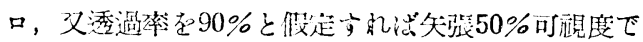

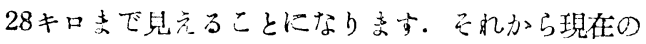

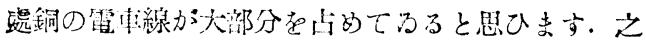

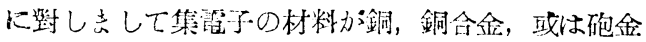

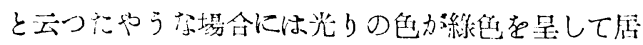

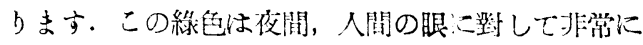
感度が宜しいので，こういふことは眼の作用上さう いふことになつてるることは御承知のことと思ひ去

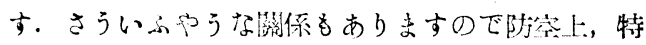
に注意要要するといふしとになると照ひます。

\section{（口）資材の消跳上の障害}

只今は防空上の障售について中」け゚たのでありま

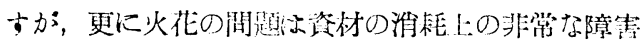

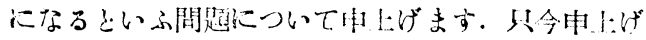

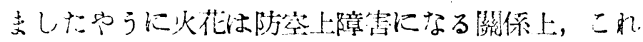

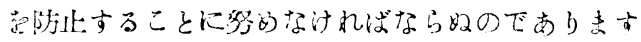

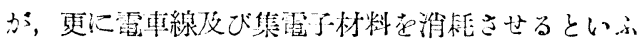

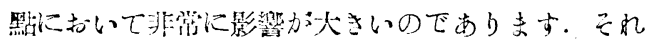

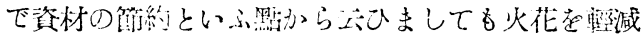

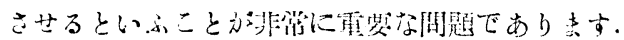

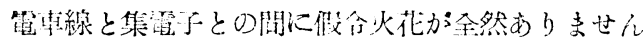

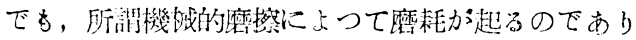

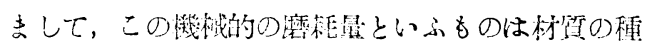

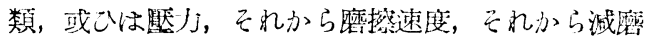

利の有無といふやうな物理的绦件で旧常に罢つて本

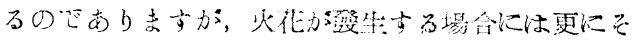

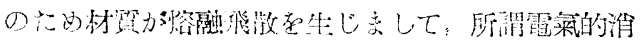

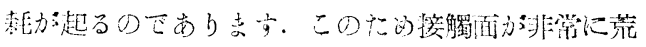

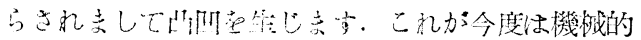

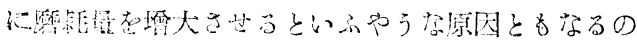

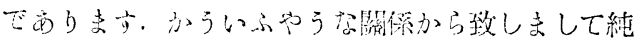

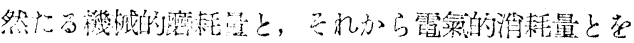

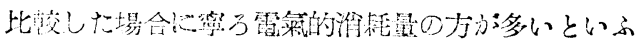

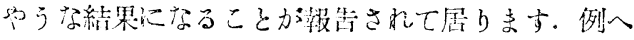

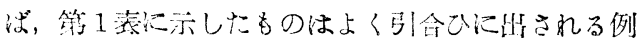

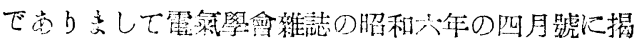
つてわるのであり克方か，硬剑電車線の $110 \mathrm{~mm}^{2}$ の

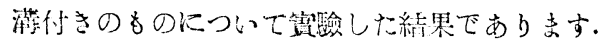

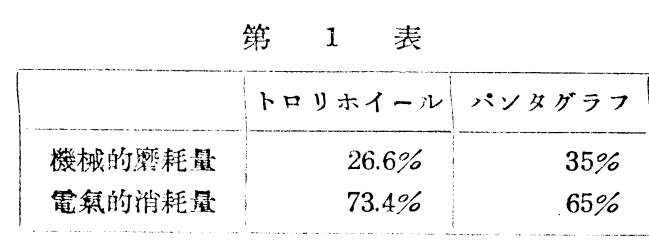

トロリホイールとパタダラフの二つの場合です 办，トロリホイールの場合機栈的㦄耗量は $26.6 \%$, 電策的の消耗量が $73.4 \%$ ，ハンタダラフの場合には

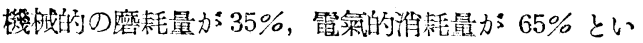
ふやうな實瞼結果も得られて居るのであります。か ういふやうに霘氣的の消耗量が非常に多いこれは

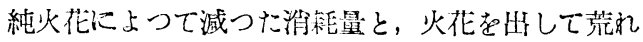
たために機械的踒耗息が殖えたのがつては居りま

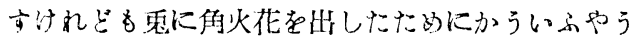
に多いのであります。かういふこと確められて居

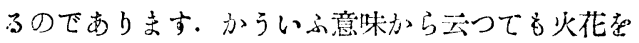

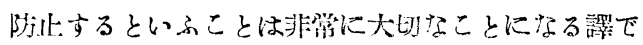
あり去声。

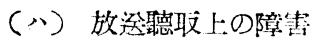

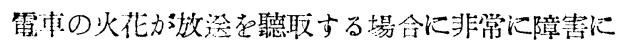
なるといふことから致しまして防空上問題峴される 以前から火花の問題か淮究されて居つたやうで西り 支す。それでラジオ㯖取障害防止委員會といふやう

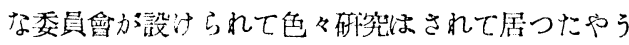

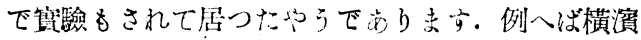

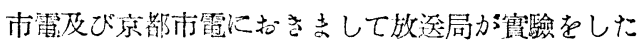
絬果によりますと, 色々蛽路をした結果放送聽取に 障害化なるのは露查の主霞動譏を流れる大きい霞流 
が障害になるのでなくて，寧ろ電登電流の 1 アンベ

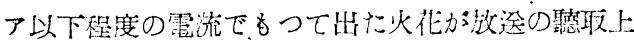

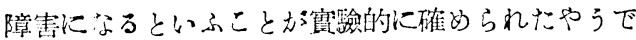
ありますからいふ小さい火花ですと,この火花汇對 して值汶蓄係にコンデンサーを入れることによつて

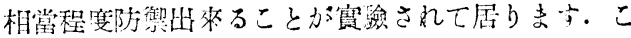

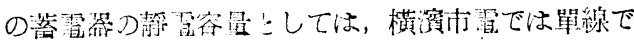

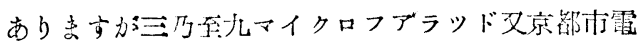
だ複滰でありますが 2 マイクロフアラッドで宜か

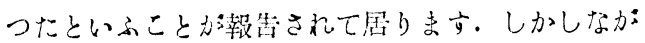

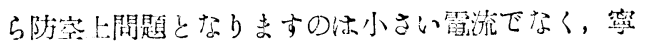

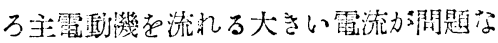
のであります。れれでこのコンデンサー

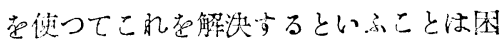

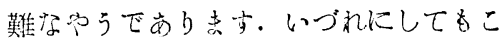

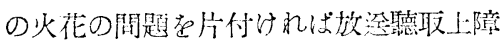

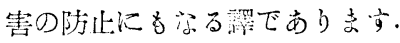

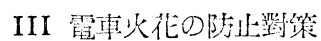

次に霓事火花の防止政籍といふことに

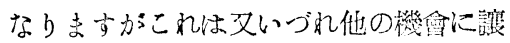

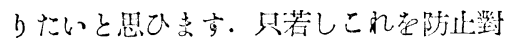
策として巻へられる慗項在分類してみま

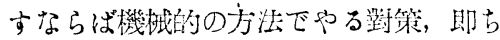

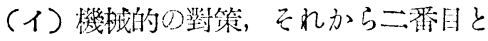
しては（口）霓氣的の對籍，三番目とし

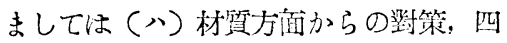
番目としましては色ヶな施設の(二) 保

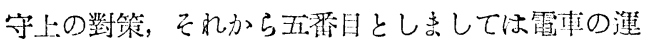

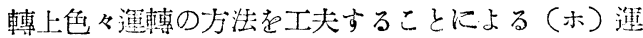
轉上の哣策，こんな風に分けることか活來るかと思

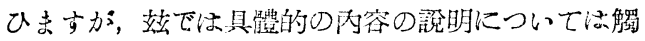
れないことに㬵します。

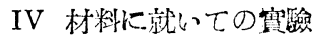

次に第四番目の材炓についての筫羷心閔して申上 げます、要するに霞䡉火花の防止對策と致しまして いいとか惡いとかといふ闃題は, 結同現埸でもつて

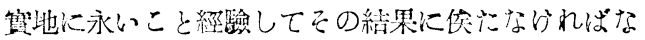
らないのであり交が，事唡によつては，例へば雷 車線の集霹子との間で若し火花を出した場合玉のた めの消㲎はとれ位あるものふといふやうなこと，或 ひは火花の明るさはどういふ材料と材料の組合せか; 一番い〉とか惡いとかいふやうなこと，焉ひは機珹 的の磨耗量はどういふ組命せのるのがとんな程度で
あるかといふやうなことを比較する場合には，瑺ろ これは材料こついて蛅踰窒的にやつてみるといふこ とも必惁ではいかと思ふのであります。さういふ

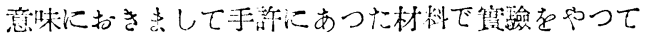

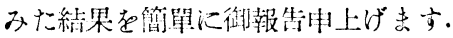

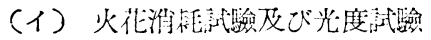

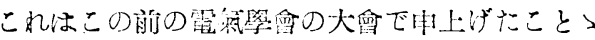

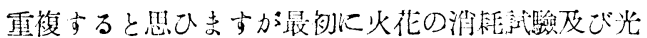

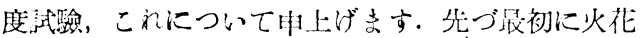

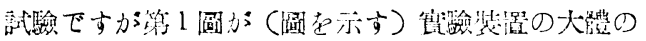

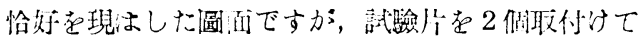
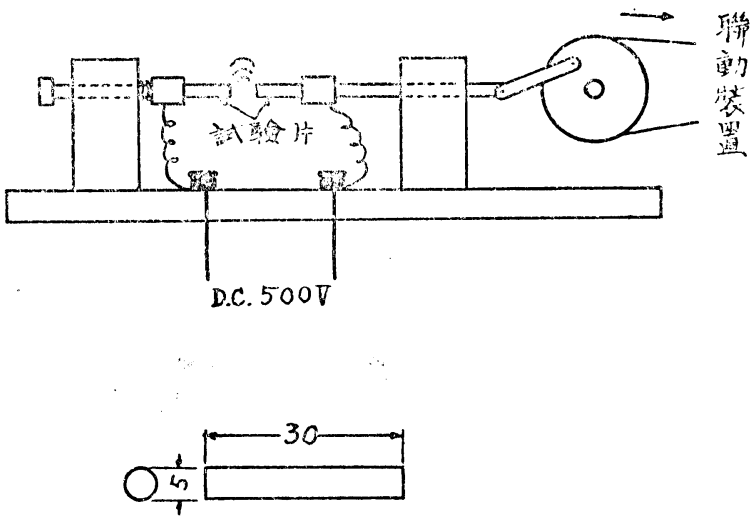

試驗片才法(粍)

第 1 圖 火花淮耗試驗裝㭡
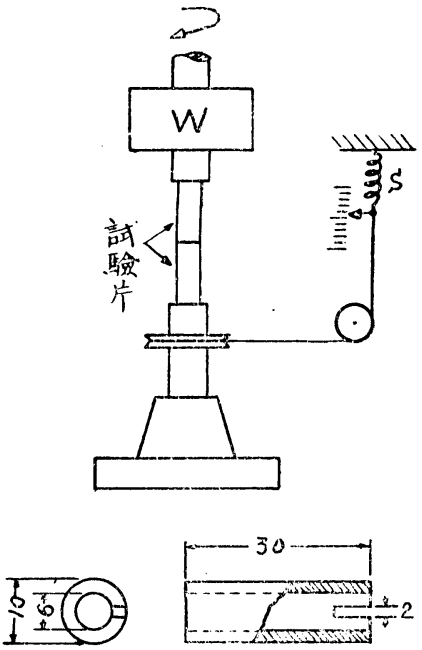

試卧版方法(粕)

第 2 㽞 機械的檗耗試驗機 


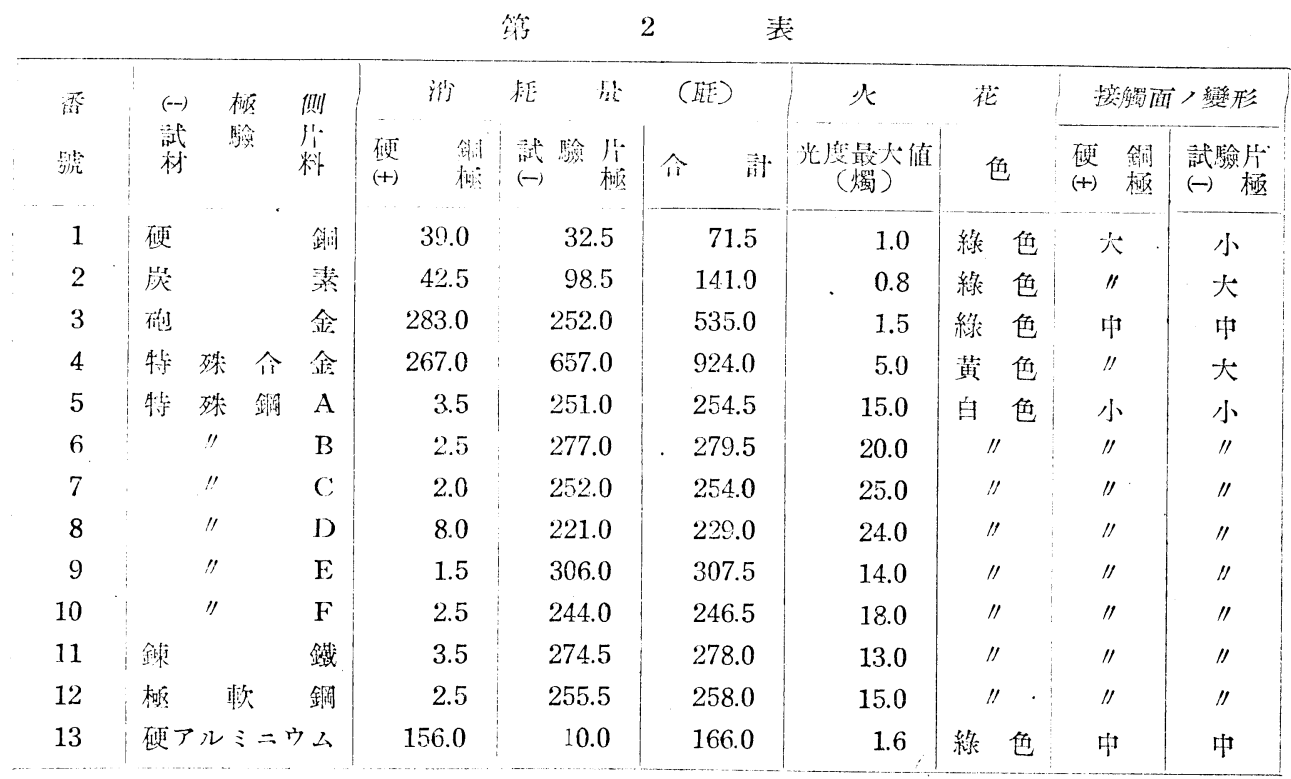

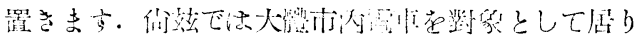

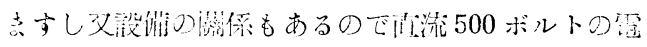

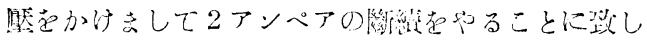

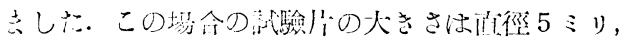

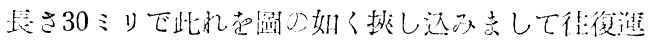

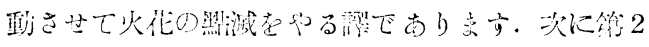

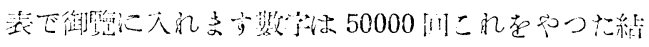

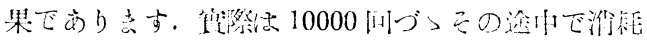
量农天秘で澌つて行くのであり去少か，絬局 50000

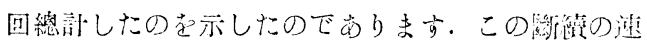

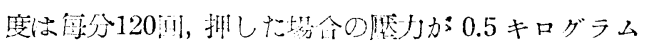

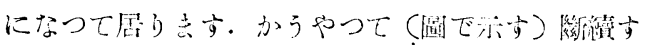

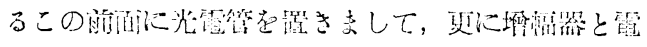

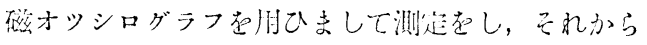

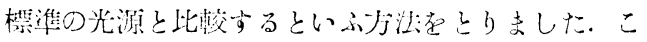

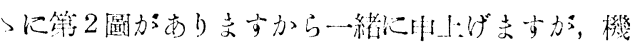

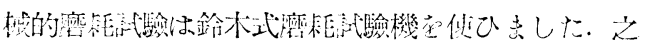

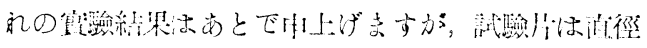

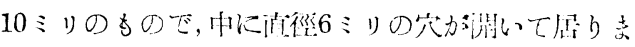
す.さうして垃さ30ミリであつて二つ取㑬てぐる

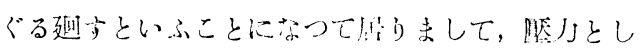

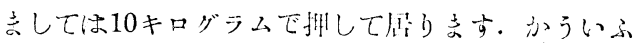

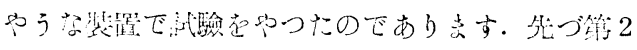

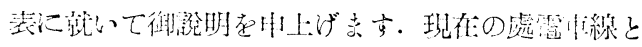

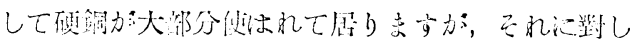

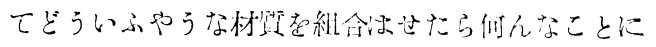

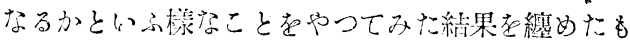
のがこの蝗でございます（表を示す）硬銅の極性を

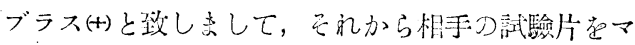

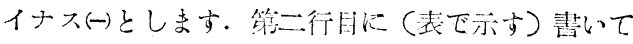

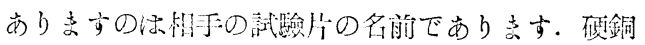
茨素, 硕金, 特殊合金, 特殊鋼, 鍊鐵, 極軟鋼, こ

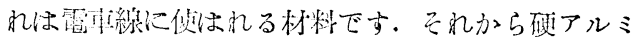
ニューム,これげけに就いて一寸やつてみた臎です。 組會はせた剒命の銅の減りか維三行目(圖で示す)

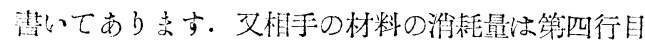
に紫いてあり支すこの次の行には消耗量の合部，そ れ加ら火花の光度の大きさが記載されて居りますこ れはオッシログラフで火花の光度の變化を一タフィ ッムに撮影しそ机の最大值をとつてあります。火花 の大きさはいつも同じではないからいくつかの最大

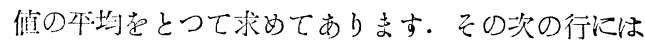

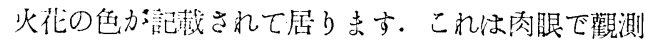

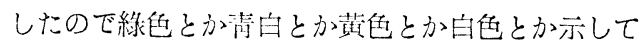

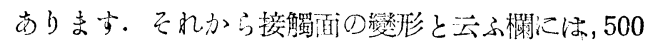

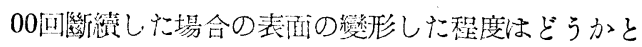
いふことを目で觀测した䋽果に基いて大中小で表は

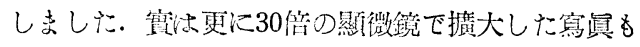
訤つてあり吉すか，それはこつでは省略して置きま す、以上の結果党胃ます硬銅といふのは銅對銅の

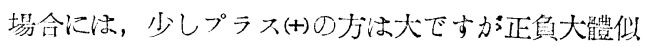

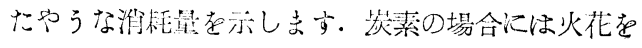


出しますと相常銅力減ります，炭素自等も非常に減

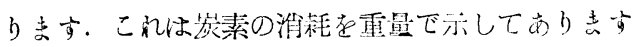

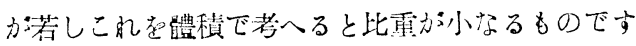
から相當大なる變形が起ることになります。花を 出すことは炭素侍して非常にいけないといふこと が云はれるのは此の篇めでありまして火花苨出すと 非常に消耗方殖光，それで炭素の面の四四の荒れ其

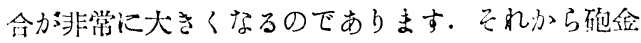
と銅の組合せの場合には銅も相堂減らすし自分も減

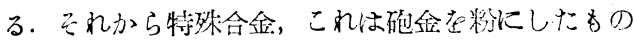
を主成分として筧結したものであります。これは火

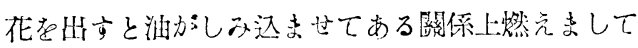

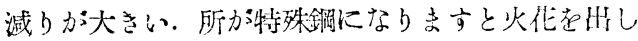
ても銅を減らすことが非常に少いのです。鐵類はみ んな同じです。鐵と銅で火花を壮しますと銅䘮減ら

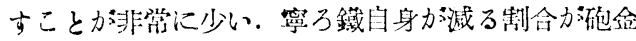
と同じ位に減るといふやうなことになつて居り志 す・これからアルミニウムの場合ですとこれはア ルミニウムがスパッターしはい材料として俌はれて るる程であります放自分自身は非常に減らないのて す.その代り銅の方を減らす。さういふわうな絬果 になつて居ります。

それから火花の光度の問題になりますと，銅對銅 といふのが制命泛暗く又炭素も暗い，砲金も一寸明 るい位で晤い：三れから特殊合金方漝い，所方鐵と のふ奴は色々なスベクトラムを含んで，標集にも使 はれるだけありまして非常に明るい白色の色在呈し ます。さういふ點から云ふとオーダーが析港ふ位

第 3 表

\begin{tabular}{|c|c|c|c|c|}
\hline 番 號 & 組 合 & 七 & 材 料 & 光度（燭） \\
\hline 1 & 極 軟 鐦 & 對 & 極 数 銅 & 20 \\
\hline 2 & $\pi$ & $" \prime$ & 硬銅 & 20 \\
\hline 3 & "I & $" \prime$ & 鍊 鐵 & 22 \\
\hline 4 & $"$ & $" \prime$ & 特殊鐝 A & 21 \\
\hline 5 & " & "I & $n \quad$ B & 30 \\
\hline 6 & $" \prime$ & "l & $\mathrm{C}$ & 26 \\
\hline 7 & " & $\prime \prime$ & $\mathrm{D}$ & 26 \\
\hline 8 & " & $\prime \prime$ & $\mathrm{E}$ & 25 \\
\hline 9 & $" 1$ & "I & $\| \quad \mathrm{F}$ & 27 \\
\hline 10 & " & 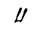 & フルiニウん & 10 \\
\hline 11 & $" 1$ & $" \prime$ & 特殊合金 & 8 \\
\hline 12 & "l & 11 & 炭 素 & 8 \\
\hline 13 & $\prime \prime$ & "I & 砲 & 9 \\
\hline
\end{tabular}

鐵と銅の間か明るくなる。こんな吅うな關係となつ

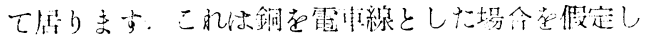

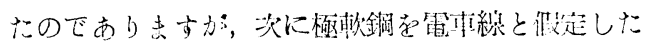
場命，己れと他のるのと就命せたらどんな明るさ

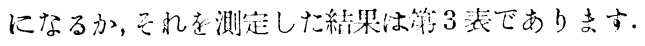

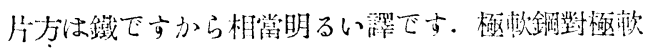
鍓は测定條作としては知版り 500 ボルトで 2 アン゚

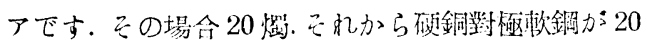
燭，鐵類は似にやうなすので相常明るいです、鐵對

第 4 表 硬銅(↔)對砲金(一)

\begin{tabular}{|c|c|c|c|c|}
\hline \multirow{2}{*}{ 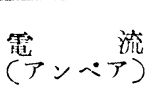 } & \multirow{2}{*}{ 光度 (燭) } & 沙 耗 & \multicolumn{2}{|c|}{ 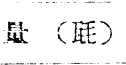 } \\
\hline & & 硬 & 笣 & 金 \\
\hline 1 & 0.8 & 70.0 & & 87.5 \\
\hline 1.5 & 1.2 & 159.0 & & 140.0 \\
\hline 2 & 1.6 & 283.0 & & 252.0 \\
\hline 2.5 & 3.0 & 368.0 & & 345.0 \\
\hline
\end{tabular}

第 5 表 硬銅(十)對符素(

\begin{tabular}{|c|c|c|c|c|c|}
\hline \multirow{2}{*}{ 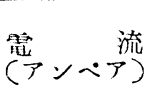 } & \multirow{2}{*}{ 光 度 (蠋) } & \multicolumn{4}{|c|}{ 消耗 神 (胝) } \\
\hline & & 硬 & 鈛 & 孷 & 素 \\
\hline 1 & 0.6 & & 5.5 & & 47.0 \\
\hline 1.5 & 1.0 & & 9.0 & & 81.0 \\
\hline 2 & 1.3 & & 22.0 & & 112.0 \\
\hline 2.5 & 2.4 & & 42.0 & & 188.0 \\
\hline
\end{tabular}

第 6 表 硬銅(十對珪素クローム鋼(

\begin{tabular}{|c|c|c|c|}
\hline \multirow{2}{*}{$\stackrel{\text { 箸 }}{(ア ソ ヘ ゚ ア) ~}$} & \multirow{2}{*}{ 光. 度 (燭) } & 淮 耗 & 基 (型) \\
\hline & & 硬銓 & $\begin{array}{l}\text { 珪素ク口只 } \\
-2 \text { 鋪 }\end{array}$ \\
\hline 1 & 9 & 20.5 & 15.0 \\
\hline 1.5 & 16 & 33.0 & 49.5 \\
\hline 2 & 30 & 12.0 & 200.0 \\
\hline 2.5 & 63 & 10.0 & 317.0 \\
\hline
\end{tabular}

第 7 表 硬銅(十)對 $13 \%$ クローム鋼(

\begin{tabular}{|c|c|c|c|c|}
\hline \multirow{2}{*}{ 雷 } & \multirow{2}{*}{ 光 度 (虽) } & \multicolumn{3}{|c|}{ 消 耗 量 (䀲) } \\
\hline & & 硬 & 銅 & $\begin{array}{l}13 \% \text { 只 } \\
-\Delta \text { 銅 }\end{array}$ \\
\hline 1 & 7 & & 1.0 & 89.5 \\
\hline 1.5 & 12 & & 1.5 & 180.0 \\
\hline 2 & 21 & & 3.0 & 315.0 \\
\hline 2.5 & 35 & & 3.5 & 507.0 \\
\hline
\end{tabular}




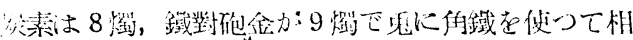

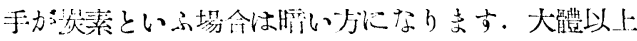

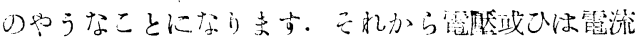

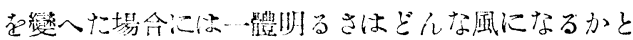

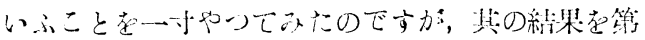

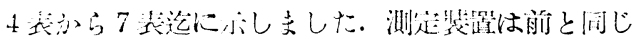

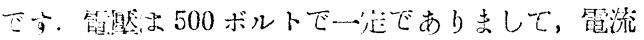

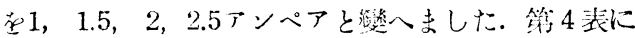

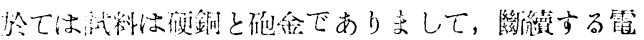

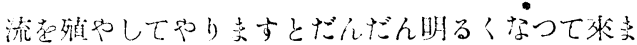

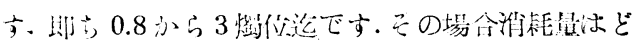

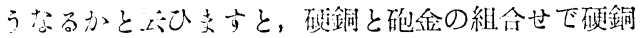

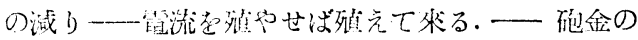

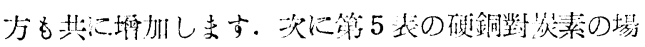

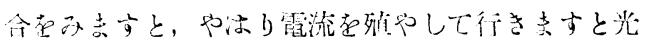

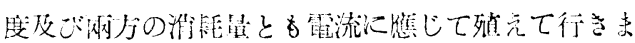

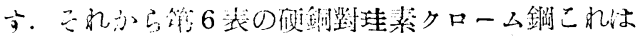

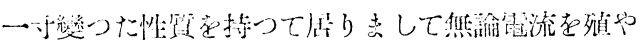
して行仿ば光度も大となり，己の明るさがどんどん

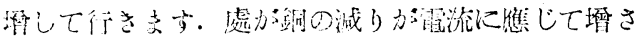

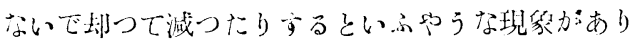

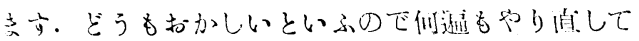

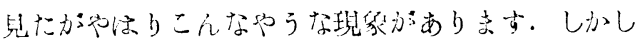

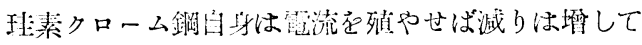

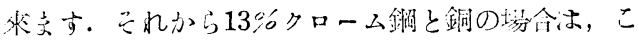

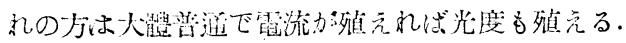

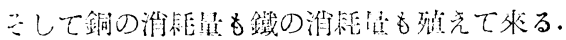

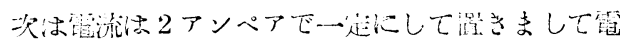

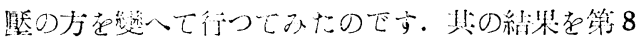

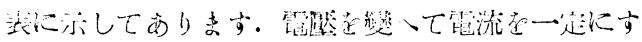

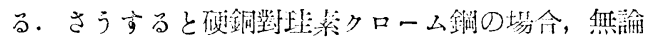

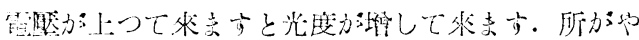

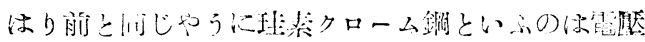

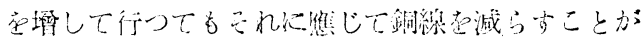

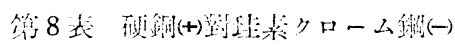

\begin{tabular}{|c|c|c|c|}
\hline 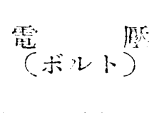 & 光度 (瀷) & $\begin{array}{cc}\text { 沙 } & \text { 粍 } \\
\text { 破 錩 }\end{array}$ & 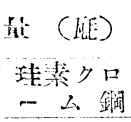 \\
\hline 100 & 5 & 54.0 & 6.0 \\
\hline 200 & 10 & 34.0 & 26.0 \\
\hline 300 & 20 & 14.5 & 56.0 \\
\hline 400 & 24 & 8.0 & 159.0 \\
\hline 500 & 30 & 8.0 & 221.0 \\
\hline
\end{tabular}

それ矰じて增加しないで却つて減つて行くやうな ことになって居り亦す。但し自分自身はだんだん減

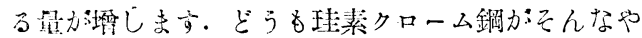

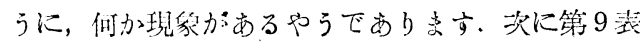

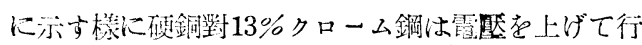

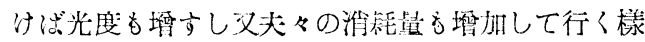

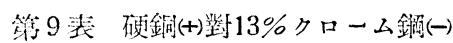

\begin{tabular}{|c|c|c|c|c|}
\hline \multirow{2}{*}{ 電 ボルト) } & \multirow{2}{*}{ 光 位（燭） } & \multicolumn{3}{|c|}{ 诮 耗 最 (瞗) } \\
\hline & & 硬 & 銓 & $\begin{array}{l}13 \% \text { ク口 } \\
\text { - } \Delta \text { 鋼作 }\end{array}$ \\
\hline 100 & 3 & & 2.5 & 55.0 \\
\hline 200 & 8 & & 3.0 & 175.0 \\
\hline 300 & 16 & & 3.5 & 217.0 \\
\hline 400 & 20 & & 4.0 & 252.0 \\
\hline 500 & 23 & & 4.0 & 315.0 \\
\hline
\end{tabular}

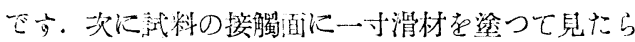
どんな風に字るかと思ひはして硬銅と㷋素との組合 や汇對してやり点した結果第 10 表に示しました。

符 10 表 硬銅(十對炭菜(

\begin{tabular}{|c|c|c|c|c|c|}
\hline & \multirow{2}{*}{ 光 度（燭） } & \multicolumn{4}{|c|}{ 消 耗 量 (庇) } \\
\hline & & 硬 & 銅 & 炭 & 素 \\
\hline 滑㓝なし & 1.4 & & 4 & & 21 \\
\hline グリス㬁布 & 45.0 & & 12 & & 23 \\
\hline 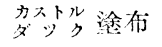 & 8.0 & & 4 & & 12 \\
\hline
\end{tabular}

但し滑劑は 1500 回每に塗布し 10000 回の消 耗星を示方

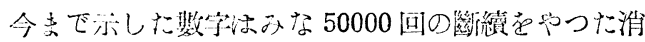

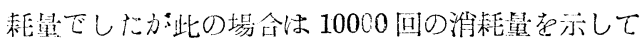

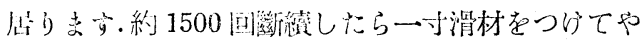
るといふやうな當てすつ法后ことをやつたのですが

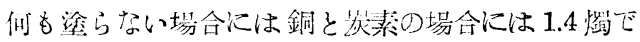

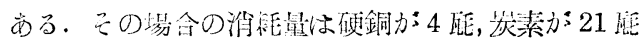
で若しグリス存禁り音すと，これはグリスが然气出 しまして非带核明るくなつてしまふのです。グリス がつついてるる開你非常に火花が明るくなつてし

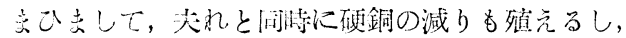

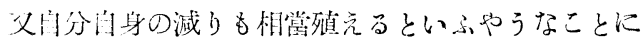
なります、カストルダックといふのがありますが,

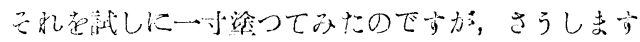

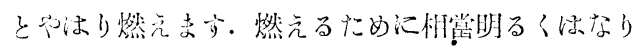
ます・これも俞つたものがなくなればやはり大鹃 1.4 
燭の明るさ（表䒬す）になつてしまふのです，力

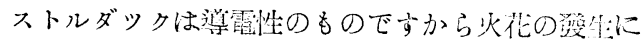

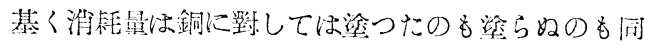

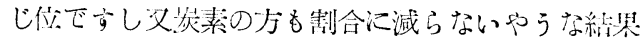
を示しました。

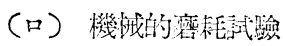

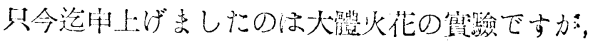

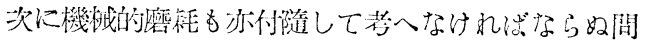

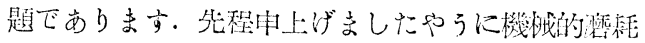

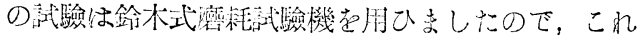

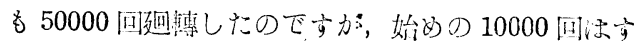
り合せといふ意味で，此の始もの 10000 国のデータ

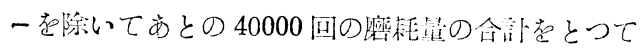

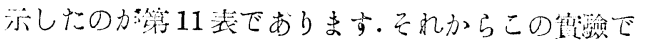

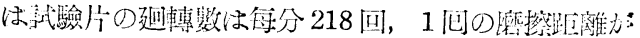

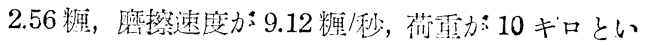

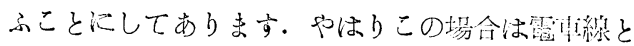
して硬銅在㑕つたものと假定しまして，表に乱成し

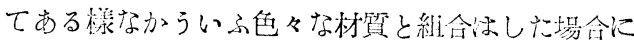

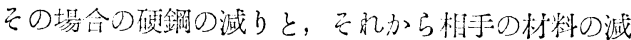

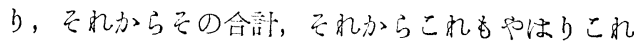

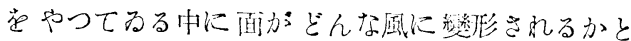

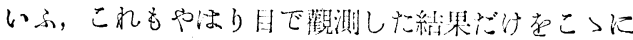

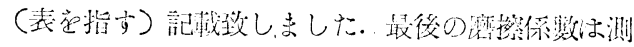

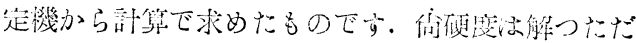

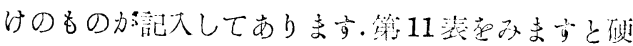

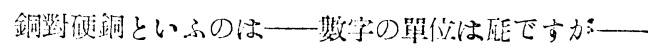

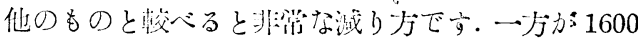

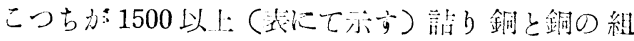

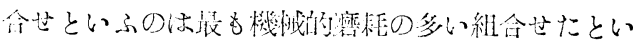

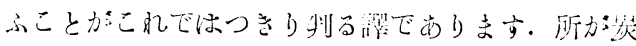

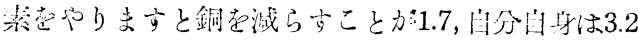

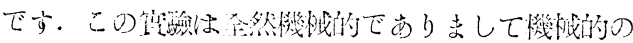

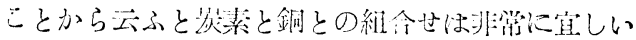
銅も你り減らないし间分も俆り減らないといること

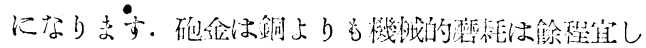

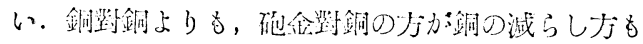

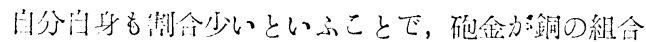
せとしてはいつのげといふやうなことになつでや

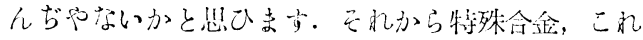

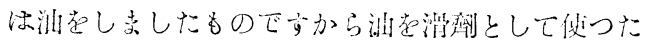

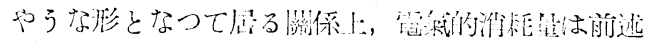

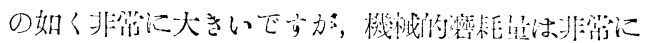

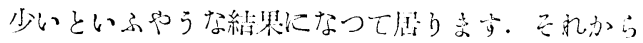

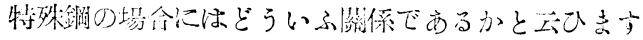

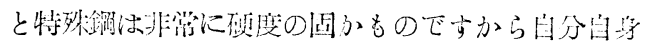
は非常に娍らないのです。しォし銅に到してはどう かと会ひま文と，この特殊銅は銅に對しては施金な

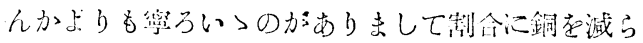
さないといふことが判つたのです. 所が䀳驖, 極軟

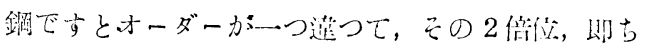

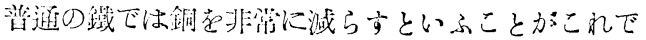

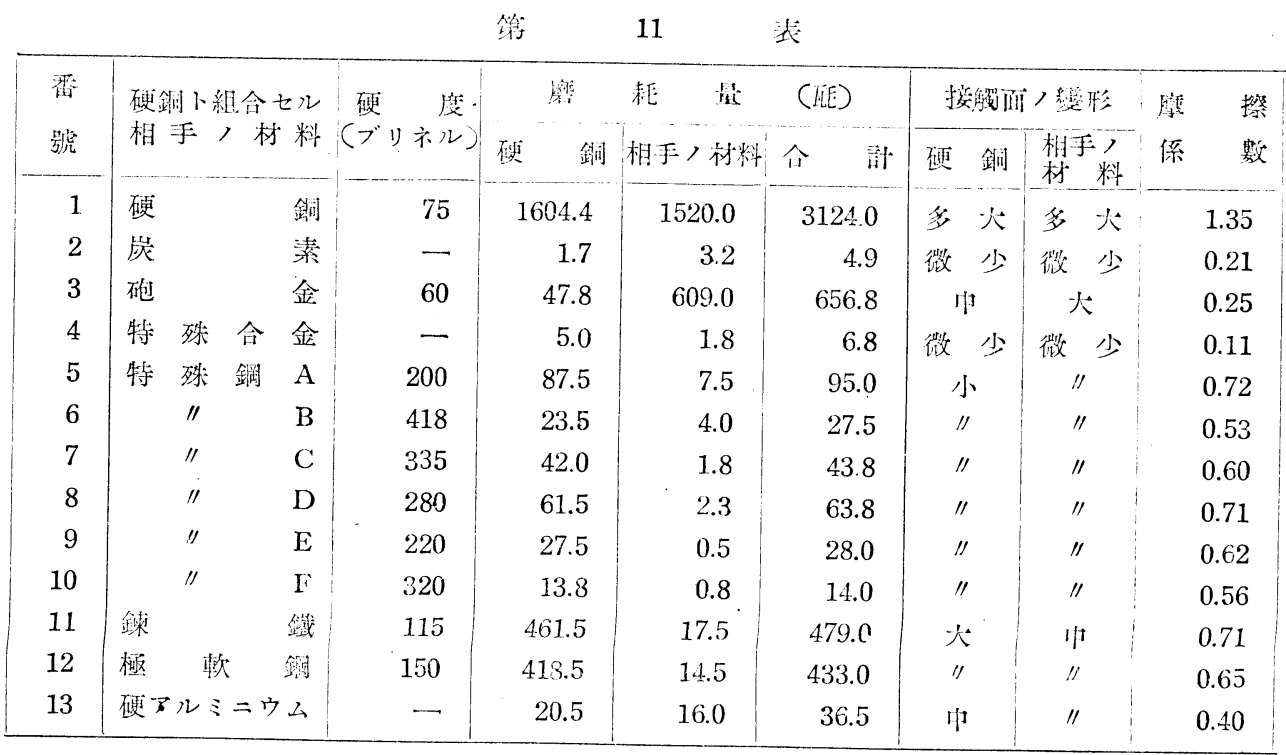


はつきり垷は礼て米たのです、特殊銅ですと銅を淢

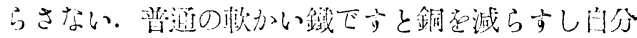

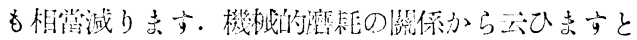

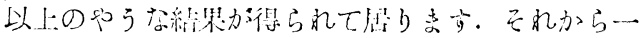

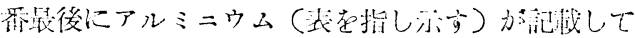

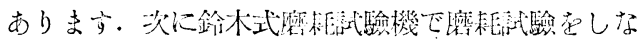

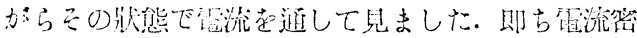

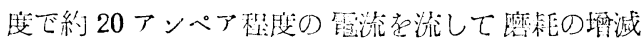

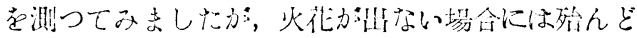

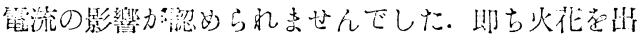

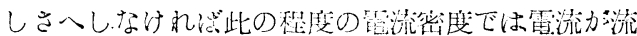

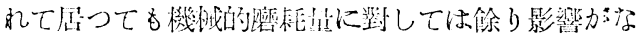
いらしいといふことが此の買驗で制つたやうな次第 です.

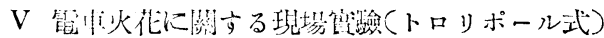

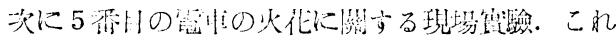

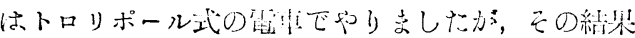

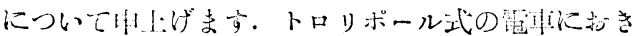

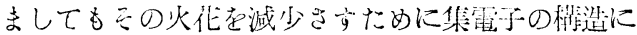

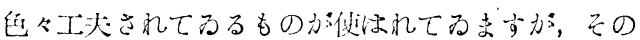

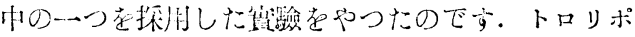

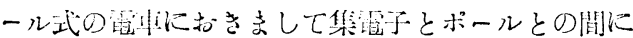

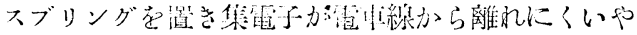

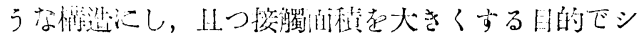

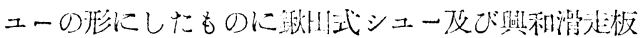

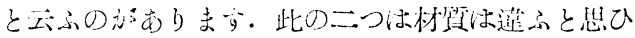

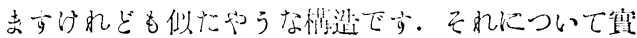

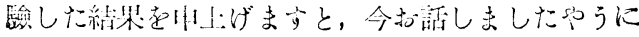

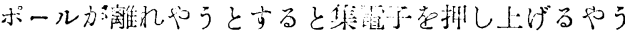
になりますから確汃火化の数は減るのでありま

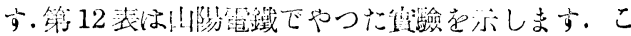

\section{第 12 装}

\begin{tabular}{|c|c|c|c|c|}
\hline & \multicolumn{2}{|c|}{ 水花發生回数 } & \multirow{2}{*}{$\begin{array}{c}\text { 走行距誳 } \\
\text { (籸) }\end{array}$} & \multirow{2}{*}{$\begin{array}{l}\text { 算驗 } \\
\text { 年月日 }\end{array}$} \\
\hline & $\begin{array}{l}\text { 䤵助式 } \\
シ \text { - }\end{array}$ & $\begin{array}{l}\begin{array}{l}1 \\
1\end{array} \\
\end{array}$ & & \\
\hline 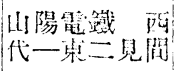 & 75 & 161 & 27.20 & 16.8 .8 \\
\hline $\begin{array}{l}\text { 间 整二見一 } \\
\text { 酉代間 }\end{array}$ & 56 & 223 & 27.20 & "I \\
\hline
\end{tabular}

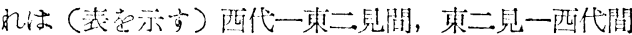

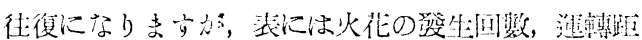

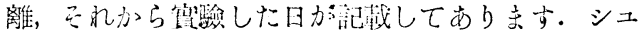

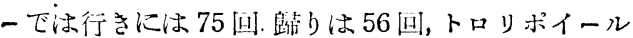

では行きが 161 回，䊆りは223回ですから此のやう

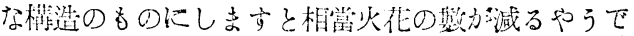
あり志方。

\begin{tabular}{|c|c|c|c|c|}
\hline & \multicolumn{2}{|c|}{ 火花發韭回铰 } & \multirow{2}{*}{$\begin{array}{c}\text { 起行距離 } \\
\text { (频) }\end{array}$} & \multirow{2}{*}{$\begin{array}{l}\text { 筫 羷 } \\
\text { 年月日 }\end{array}$} \\
\hline & $\begin{array}{l}\text { 與和 } \\
\text { 湦走板 }\end{array}$ & $\begin{array}{l}\text { トロリホ } \\
1 \text { - }\end{array}$ & & \\
\hline 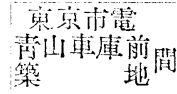 & 44 & 187 & 6.971 & 17.9 .5 \\
\hline 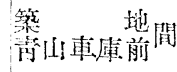 & 61 & 177 & 6.971 & $" 1$ \\
\hline 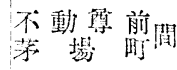 & 58 & 130 & 2.024 & 18.4 .2 \\
\hline 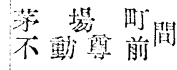 & 46 & 117 & 2.024 & $" \prime$ \\
\hline
\end{tabular}

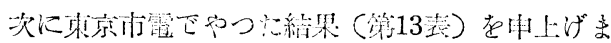
タと舆和滑定板とトロリポールと在比較しますと杼

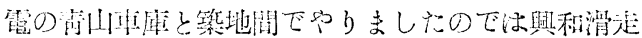

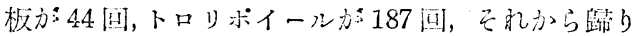

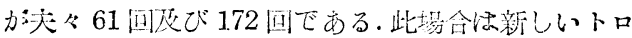

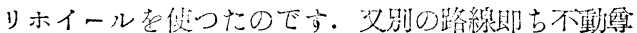

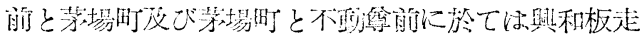

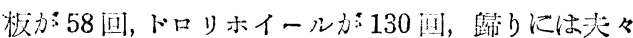

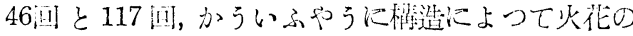

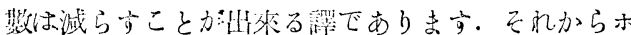

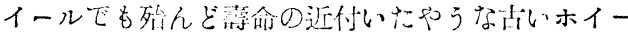

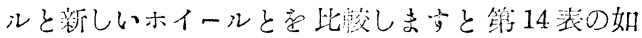
くやはり新しいのは数が少くて古ホイールは殖えま

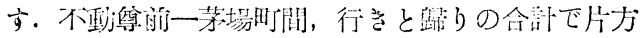
は178回，片方は232 四，即古古いの主いといふ ことになり去す。

\begin{tabular}{|c|c|c|}
\hline & \multicolumn{2}{|c|}{ 灭花發生回數 } \\
\hline & 新ホイール & 古ホイール \\
\hline 不動尊前 一 茒場町間 & 100 & 132 \\
\hline 茅場町一一不動票前間 & 78 & 100 \\
\hline 該 & 178 & 232 \\
\hline
\end{tabular}

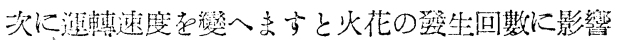

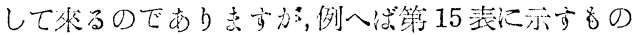

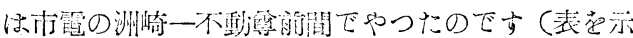

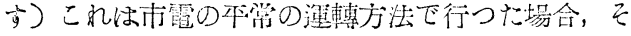

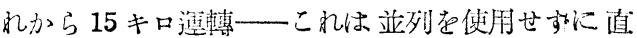




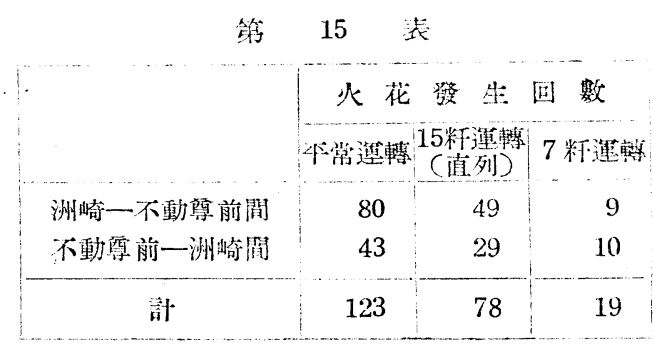

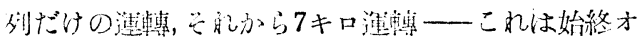

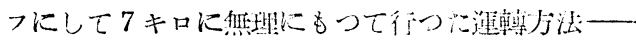

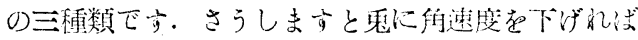
夫れに雔じて合計で $123,79,19$ といふやうな風に

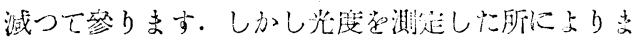

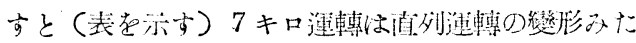
いなもので數は減りますか，出た火化の明るさは潈

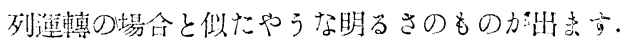

次に今まで朋上淁しいのは火花の數についてで ありましたが, 翼際渾輞中に發しけ火花の光度はど んな程度のすのであるかといふやうなことを测运し

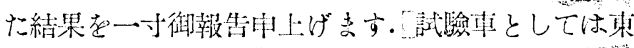

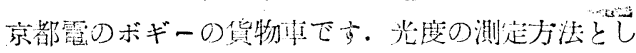

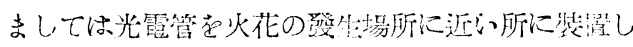
まして，それと燯幅器と，それからこっで中トげる

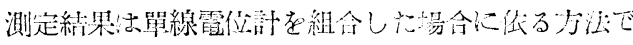

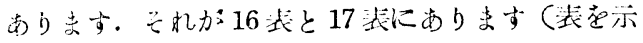

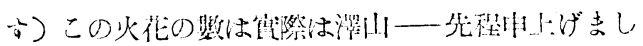

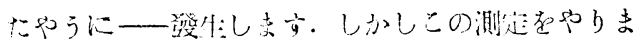

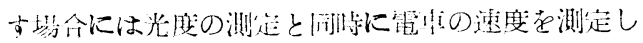

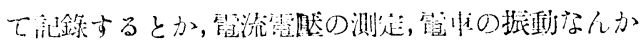

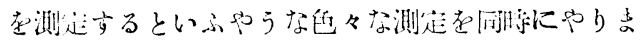

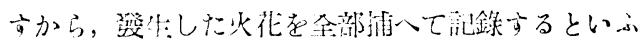

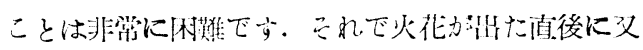

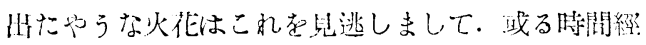

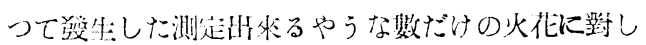

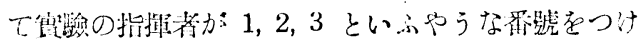
て行くやうにしまして，无れに相学するやうな火花

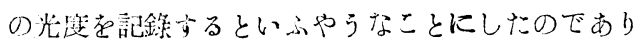

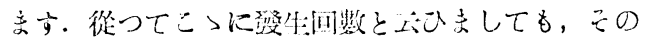

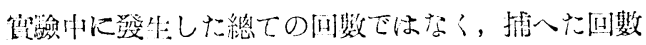
だけについて山」げることになる㒛でありま去。例

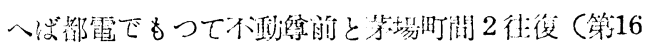

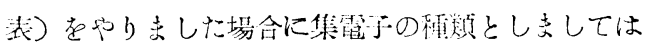
カーボンシュー, 興和滑走板, 硕食ホイールの新,

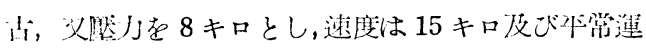

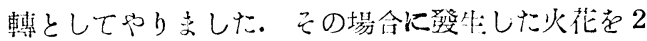

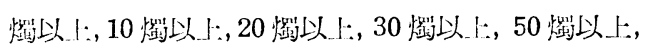

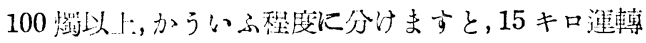

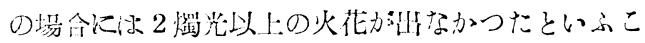

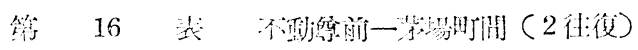

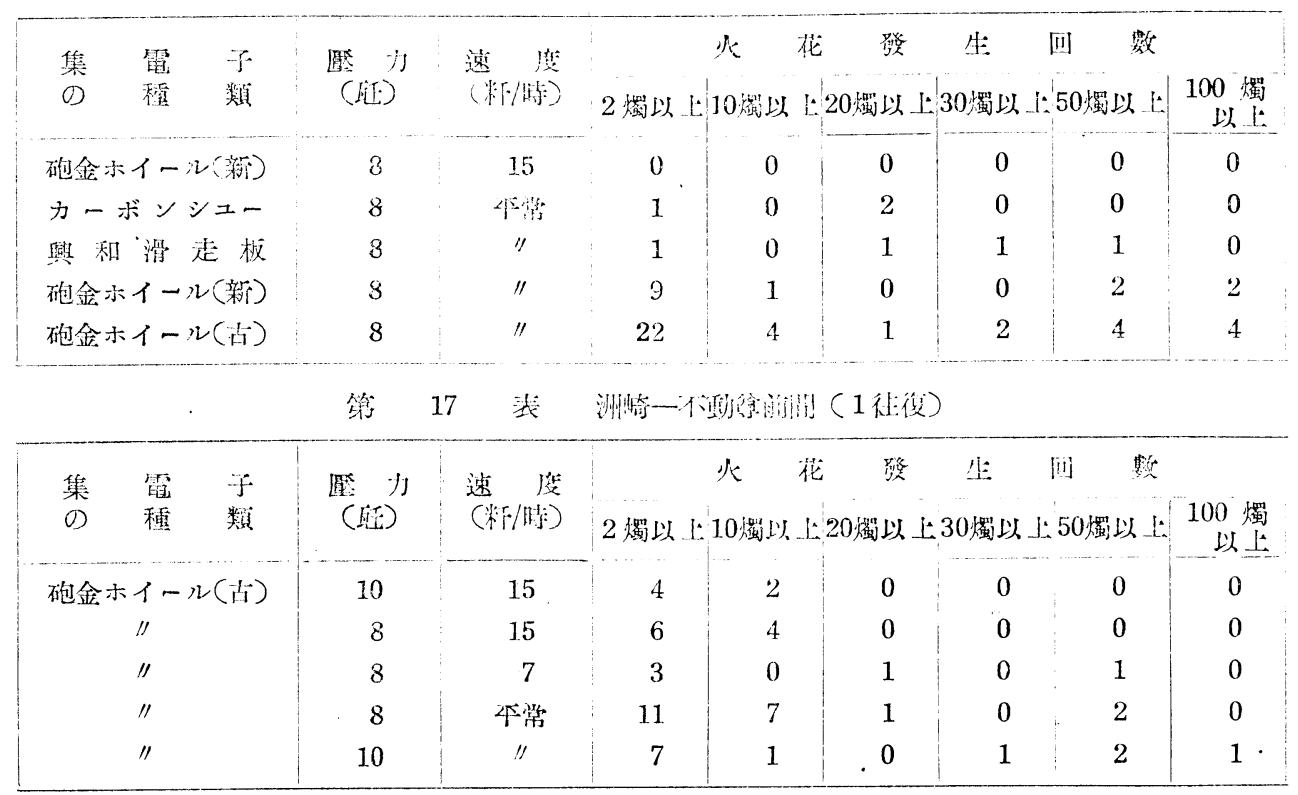




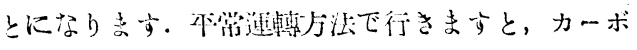

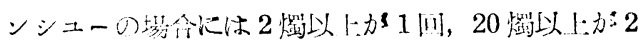

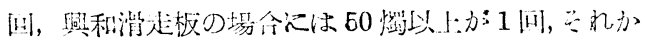

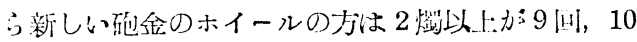

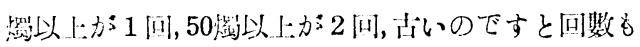
多いですが更に加うい小(装存指す) 明るい奴去で

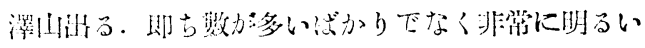

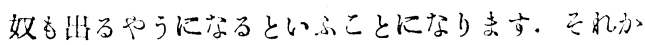

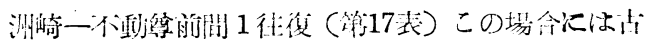

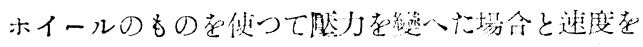

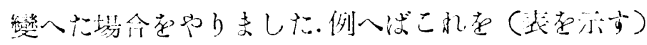

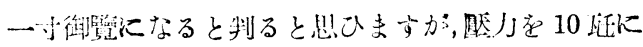

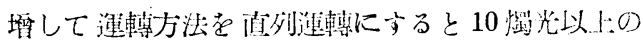

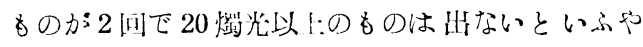

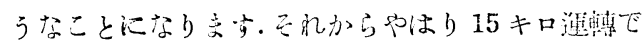

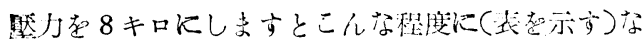

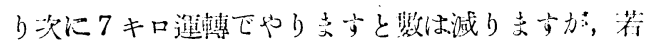

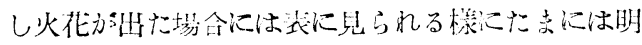

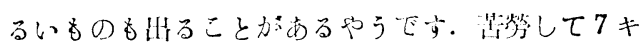

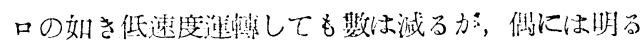

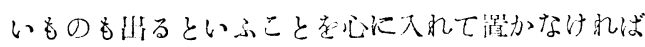
ならぬといふことになる㒛であります。なほこの䉓

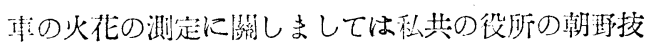

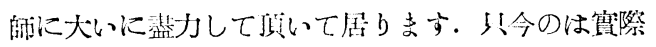

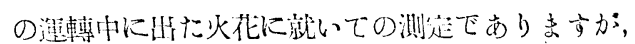

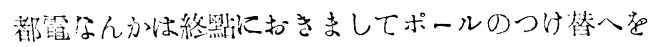

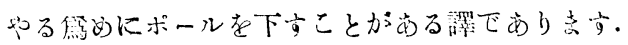

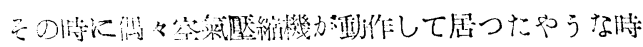

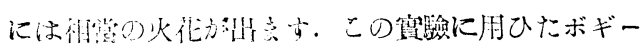

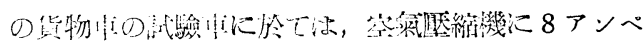

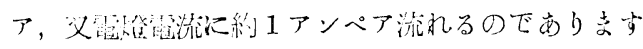

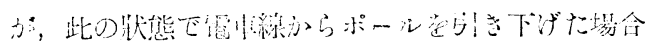

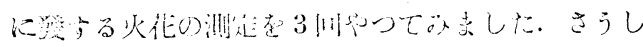

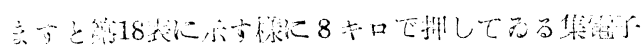

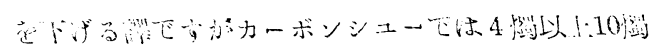

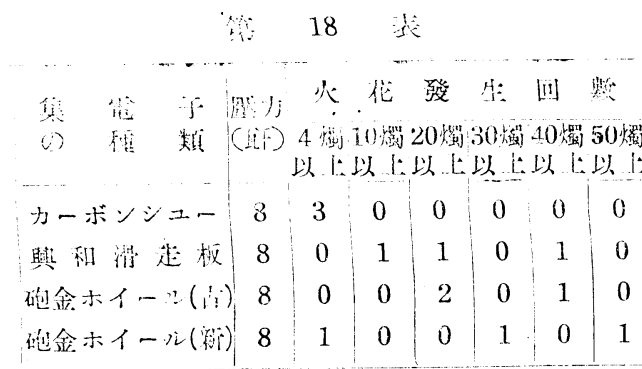

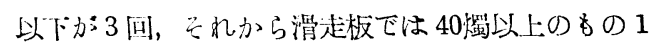

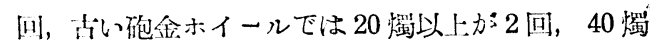
以!加 1 [四，新しいものに於ては 4 嘖以上の場合 30

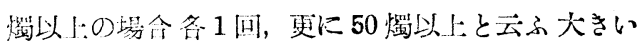
奴心训たこともある.以ははボール式電車について

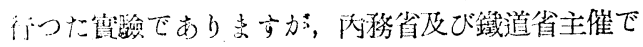

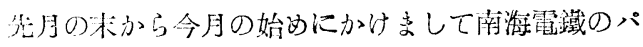

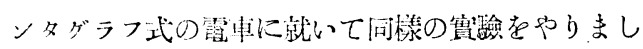
たが，それは合整理中であり支すし，いづれ內務

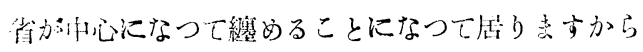

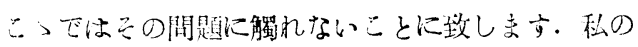

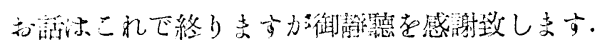

(推看)

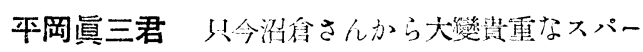

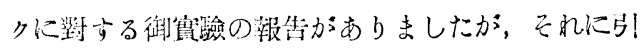

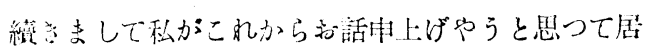
りますことは，こつ鞂年前汃ら鐵道省阿におままし

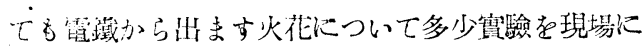

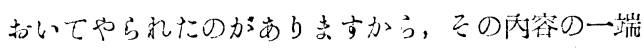

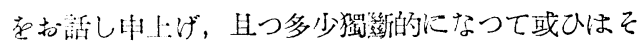

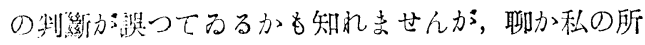

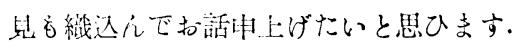

只今和敌しました鐵道省闯に於て行ひましたス

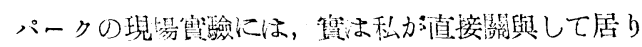
ません時代の記錄でありまして，本汸私からお話申 はげますのは少しく當在失してるるやうに思ひます けれも゙す，照明學會からたつての御茬望すありまし

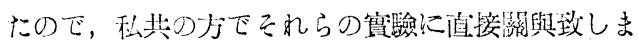
したちの汃らデーター存蒐集しましてお取次ぎの程

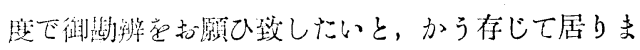

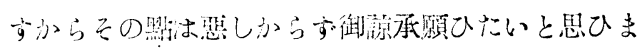

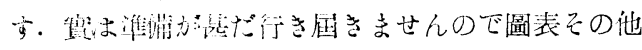

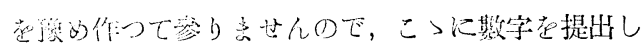

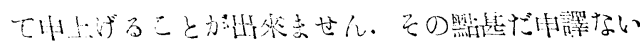

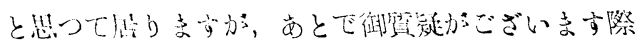

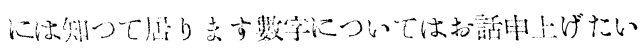

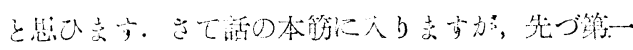

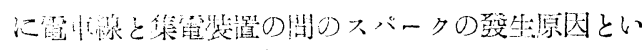

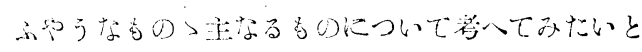
岕心ます。

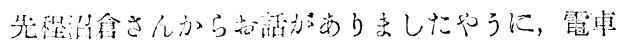

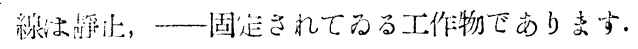


その下を起ります車は絶えす運動して店ります。. そ

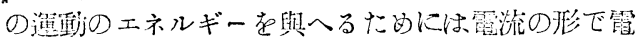

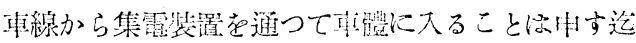
るないのでありますが，この際に国定して居ります

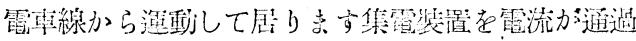

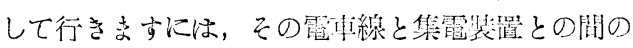
接觸裝置力淮行中如何なる藋合，如何なる時におい てを接触か浣全でありますならばスパークの䦌題が 起らないのは堂然であります。

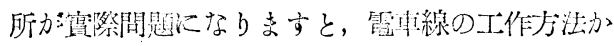

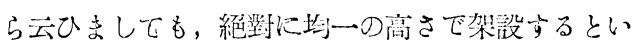

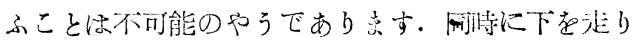

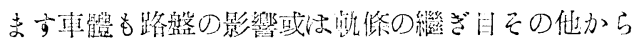

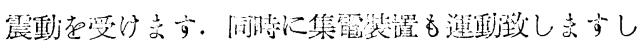

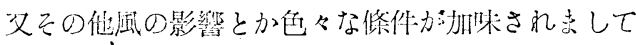

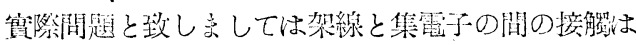

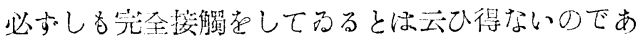

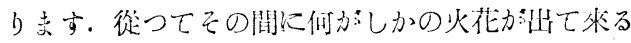

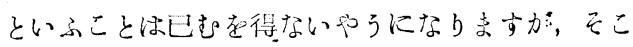

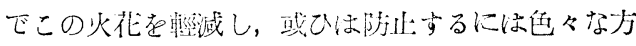

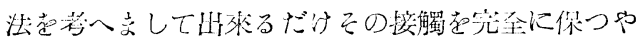

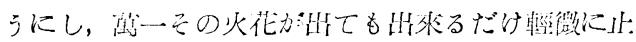

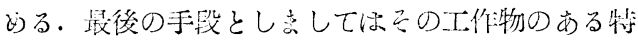

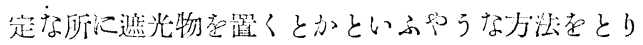

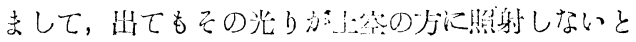

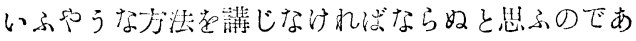

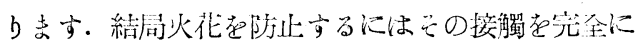

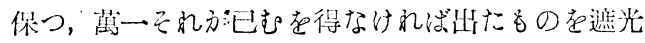
するといふやうな方法莡者へるといふことは誰しも 思ひ付くことであらうと存します。

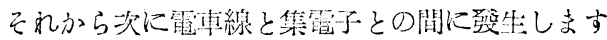
火兆の色はどんなむのであらうか。これる先程沼倉

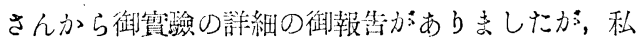

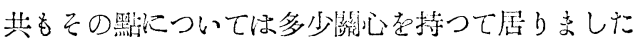

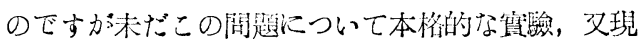

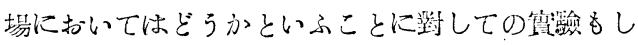
て居りませんが，たず極く䦬䉓ではありますが，或 る機會に色ばどんなものだあらうかといふことにつ

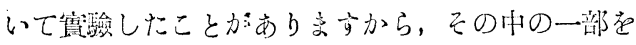
中上げたいと思ひます。

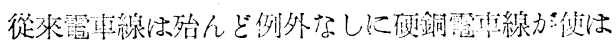

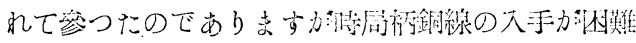
になりまして，最近においてはアルミ合金線，或ひ

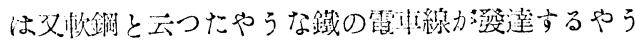
な侧们にあり紊す。

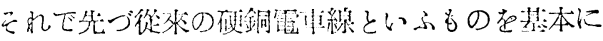

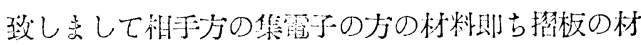

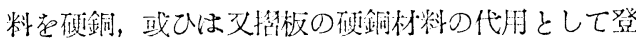

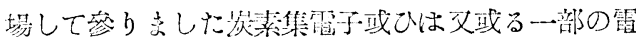

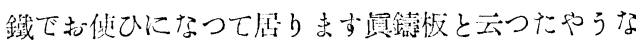
さういふ材料の組合せ走變入た莂合に火花の色はど

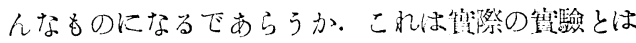

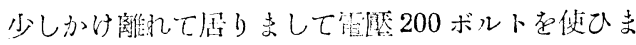

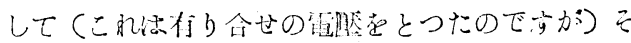

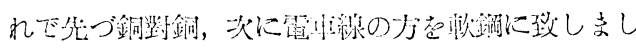

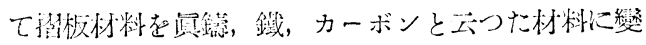

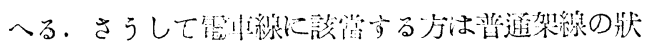
態に似せましてダブルイーヤで悢ぎ合して，この綧

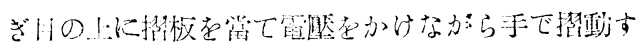

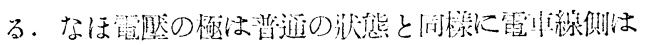

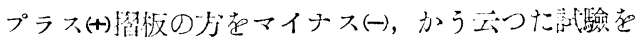

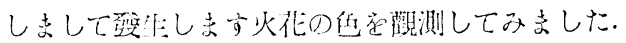

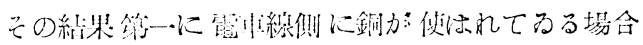

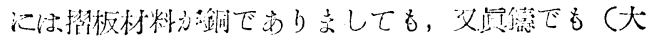

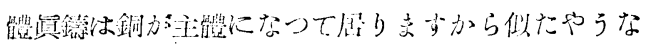

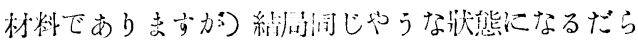

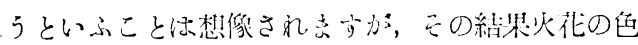

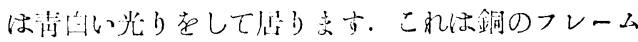

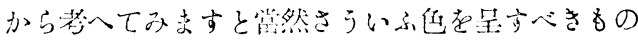

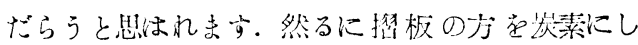

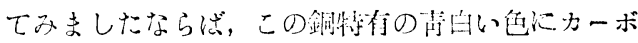

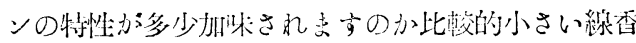

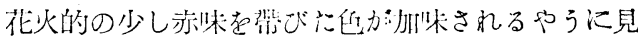

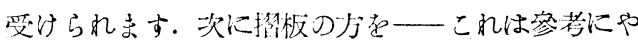

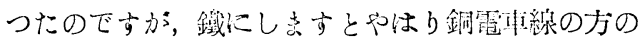

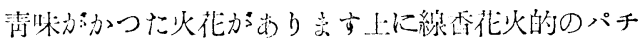

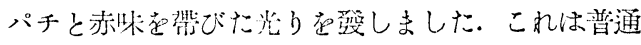

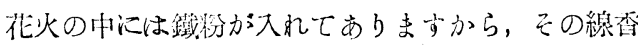
花火の色と似てるるのも祭のやうに想はれます。

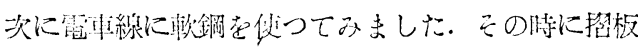

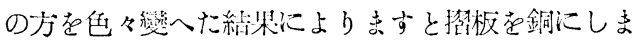
しても，畏籍に致しましても火花の出は大分前と趣

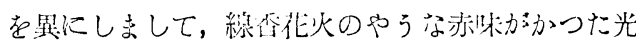
りふかパチパチと，且つこの化火の大きさは非常に小

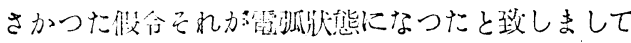

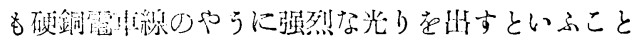




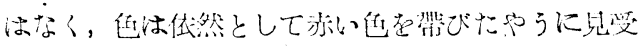

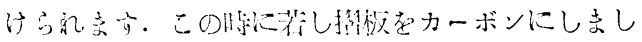

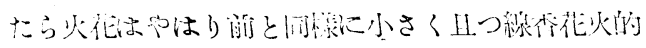

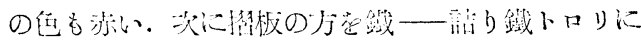

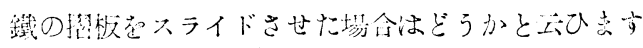

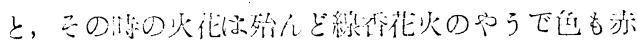

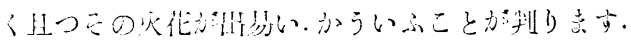

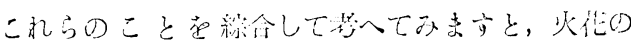

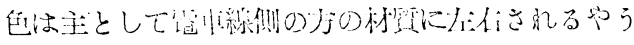

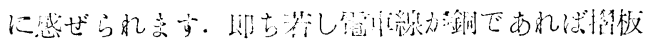

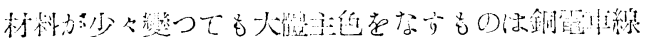

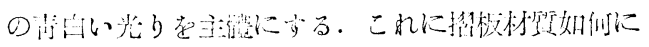

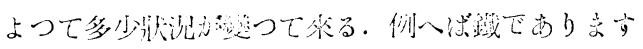

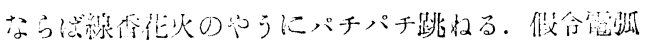

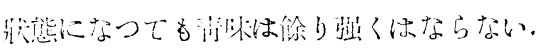

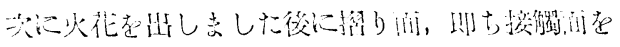

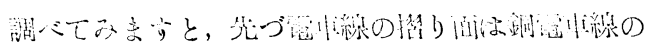

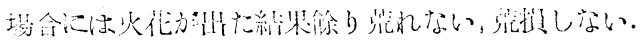

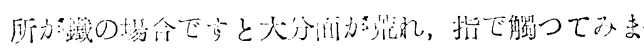

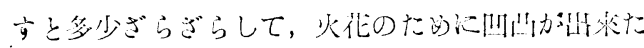
のだといふや弓な感じ就し支す。これらのことか

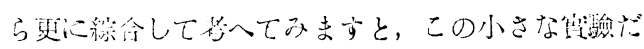

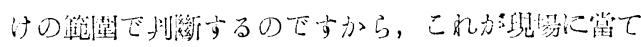

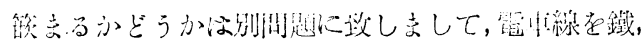

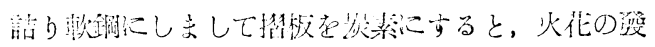

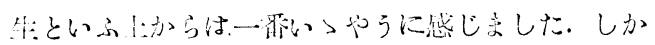

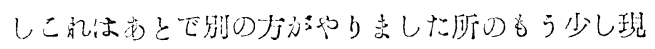

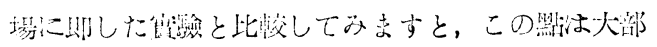

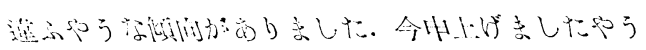

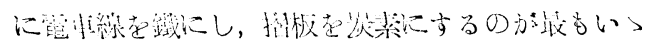

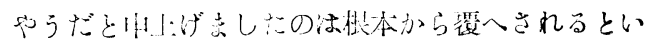

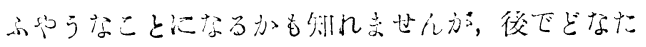

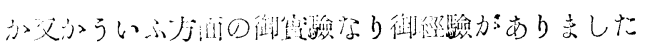

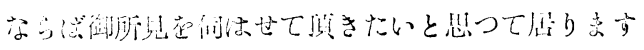

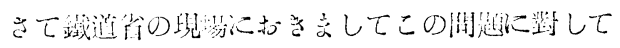

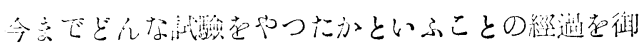

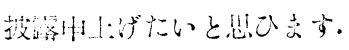

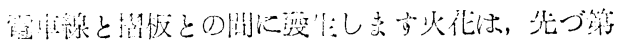

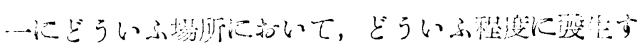

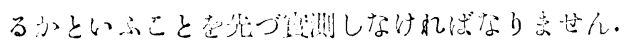

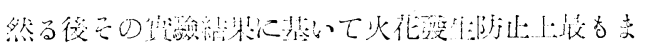

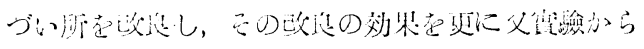

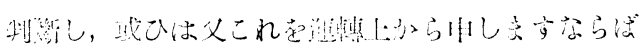

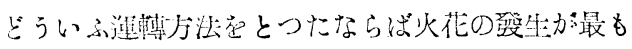

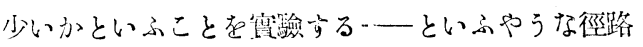
左とらなければならないと思ふのであります。省に 括き气しては昭和 11 年 12 今中旬に, この問题に對

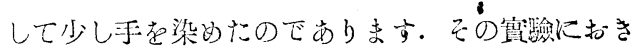

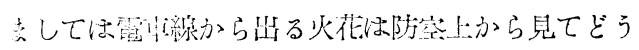

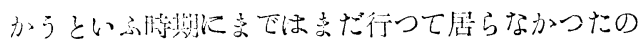
でだ゙これは別の腎味があつたのであります，若

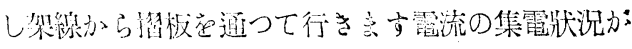

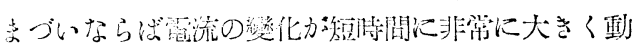

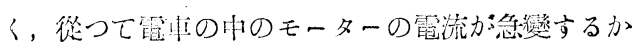

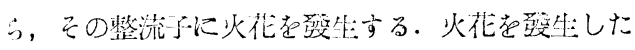

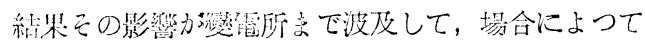

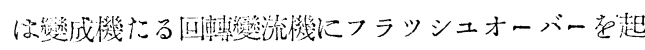

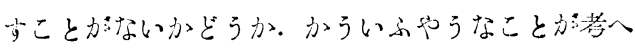

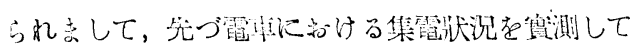

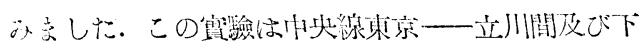

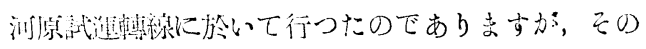

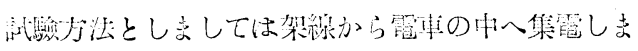
すとのパンタグラフの集雷子とメーンモーターとの

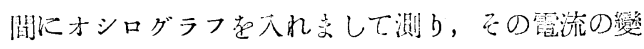

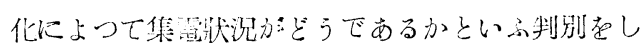

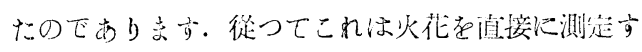

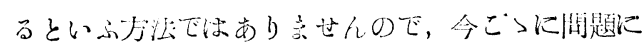

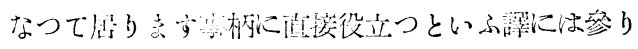

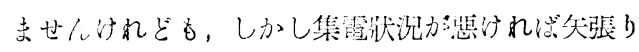

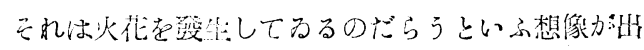

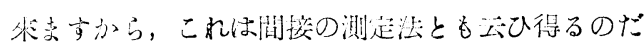
らうと想ひ高す。

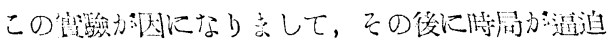
して參りさした結果スパークの武驗をしなけれ济な らないといふ羾沉になり紊して，昭和15年 5 月上:旬

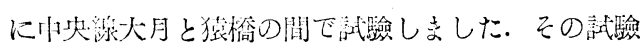

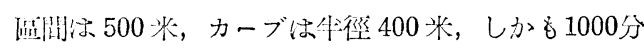
の 25 といふ上り勾配の所で公配線の影嚮，己れから

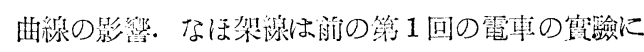

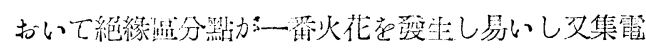
る非简に留心といふことが判つて居りましたので特

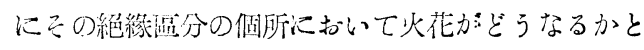
いふことな⿻一定温聞を何回も往復し,さうしてその

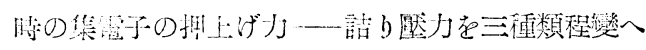

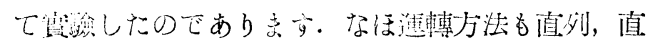

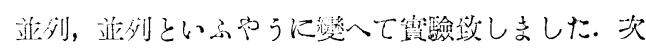


にスバークの測定方法恃どうするかと申しますと，

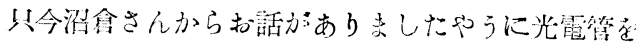

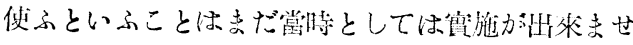

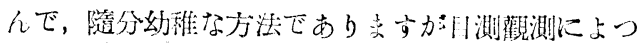

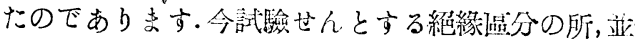

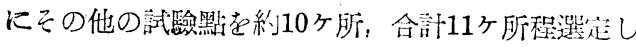

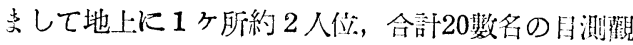
測員を配置しました，さうしてその出ました火花に

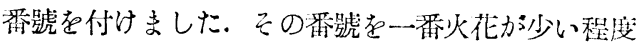
のもの，例へ炏火花がー小と云つても程度が非 り寺せんが極了僅かな火花か波射して見えるとい小 程度のものを火花小，これ存更に三つに分けまして 一番，二番，三橎とい小引うに分ける。次炏花の 大きさが中，これはパンタグラフの集琵子の舟の附

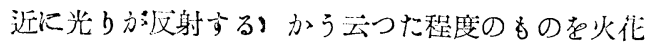

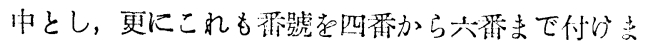
した。正れから最後に火花大といふのは線路附近の

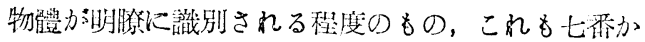
ら儿蕃索で付けた。永らいふ至つて幼稚な方法です が鬼化盾これで大體の大きいか小さいか，中修汃と いふ程度のものだけの，いくらか走最的炕近い制别

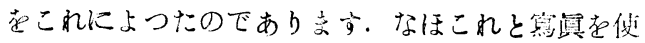

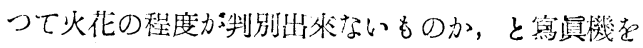

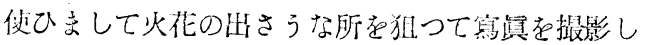
た．所方その䓨睆はまだ始めてのことでありました ので, 窵真撮影の結果は㱠んど失敗と申してよい位 でその結果から判楌するといふことは出來なかつ たのであります。結局目測の判定黙數と，それから

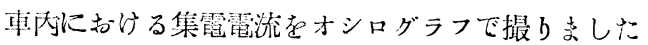

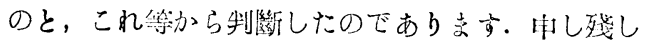

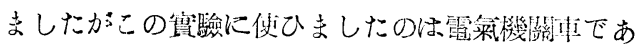

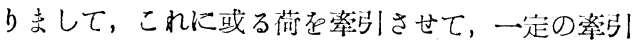
トン数汇よつて霞流を色々變へて翼踰したのであり 去古.

その次に眧和16年 7 月下旬に，これも下河原武連

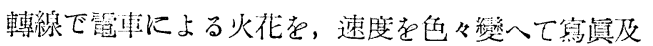
び目測の方法で行ひました，所がこの㸝は餘り定最

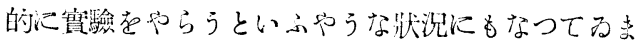

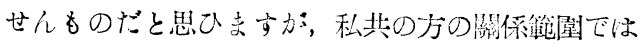
關與して居りませんので, その數省的データーはこ

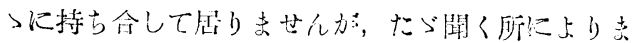

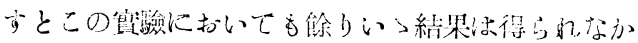
つたやうです.

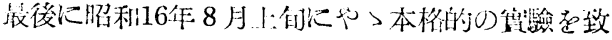

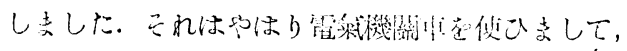

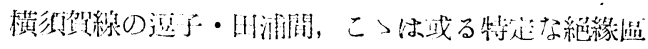

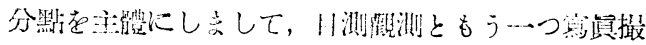

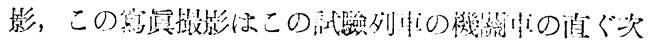

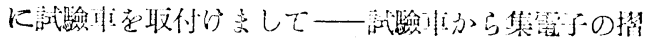

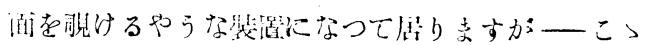

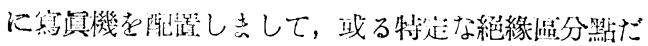

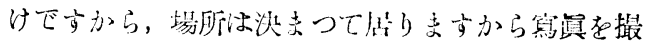

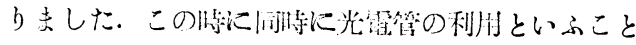

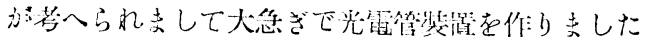
のですが汕た留流在オシログラフに入れるには场幅

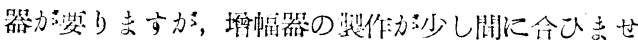

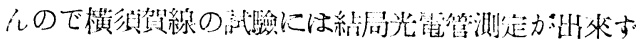

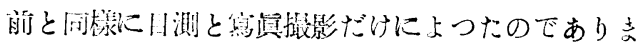

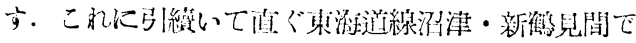

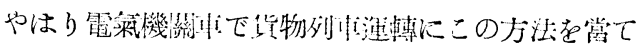

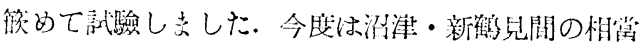

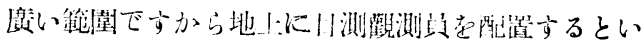

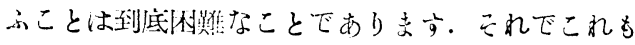

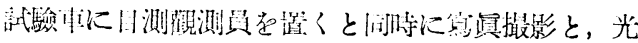

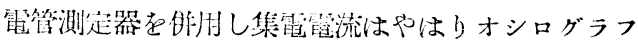

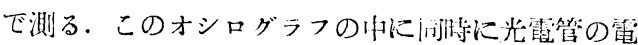

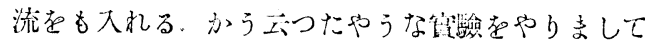

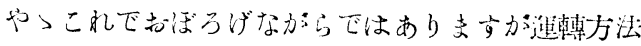

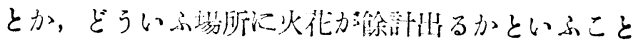

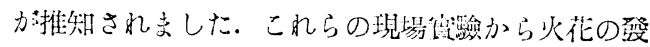

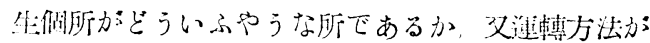

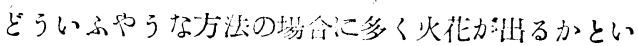

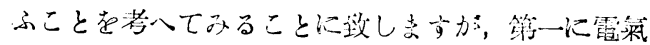

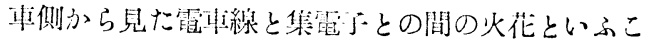
とについて少し者へてみ市す。

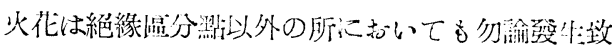

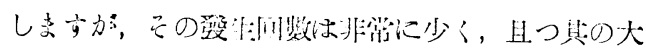

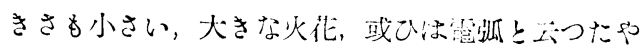

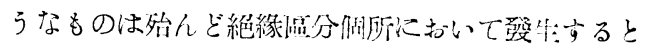

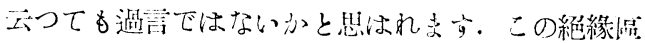

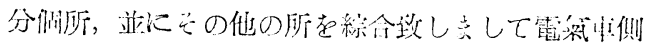

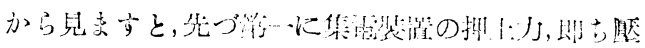

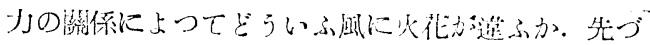

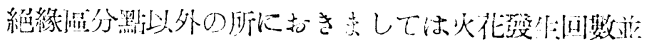

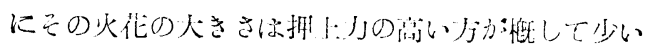

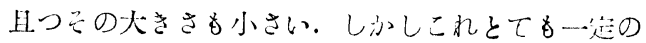


限度がありまして，この赛签にまいて行ひました押

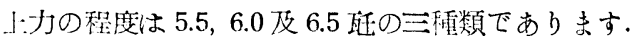
その筑國內ならば今のやうに打されるやうな骕が致 しま市.

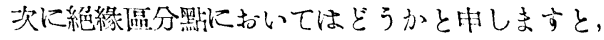

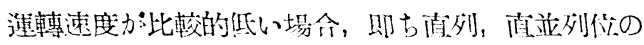

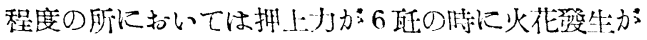
一番少かつた。これよりす速度の高い並列㴖轉をす

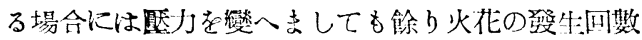

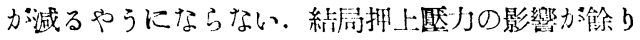
ないやうに考へられます。結局押上力揞く且つ速

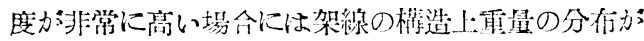
ぞうしても一定に行きませんし，且つ絕線满分の所 においては相賞雨量が大さいから，梦ひ高速度にな り圭すと集溉与がジャムプし去す。さういふやうな

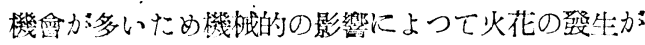
㓐加するのだと考へられます。だすから堅力を6酉 以上に假命高的ましてる火化發牛の防止に對しては 餘り效果力淿い。

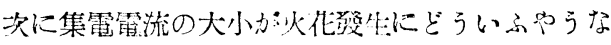

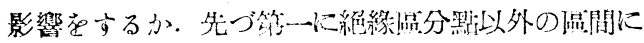

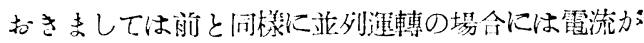

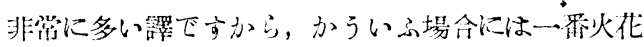

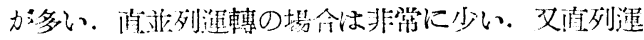

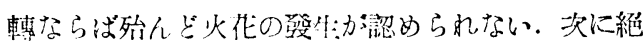
緣盆分黙ではどうかと六ひますと，集電子の揞板が

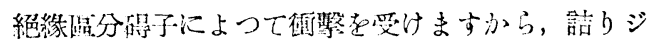
ヤムプしてそのために生する火花と, 今一つは集電

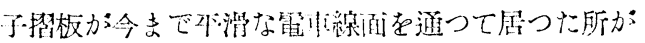

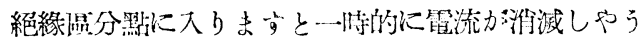

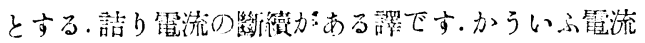

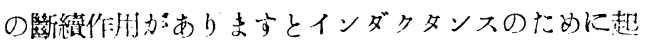

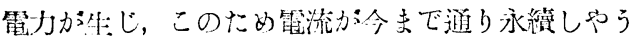

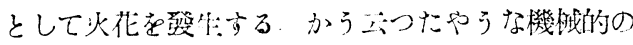
ジヤムブと，電氣的のインダクタンス作湖によつて

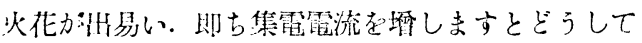

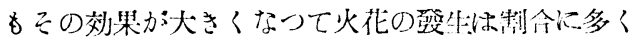

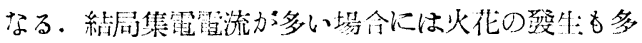
く，その大きさも大きくなるやうに想像されます。

集霞子の润數がどういふ栭に影響するか。これは 耧新しくこつで刊はげませんだすお判りのことつ思

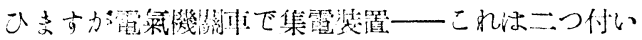

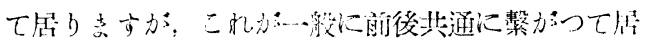

り，それからモータ一回路へ笨ります。この集電装 置の佃数と非しますのは機到車でありますれば二㑑 だす.この二個の集雷装置の中一つを下げて,一つげ けで茜轉してるるのが普通ですが，一佃丈けで集露 するか又心二個で集溉するか。るれから更に連結溉 本になりますと動力車が連結されて鬼り志すならば

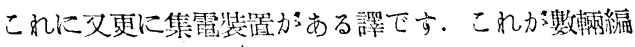
成になりますとこの中何かしか怯附隨車で集霞装置 が利いて居りませんか，次の本に若し唾力車があつ たとするならば，るれに集露装置力付いてるる。か

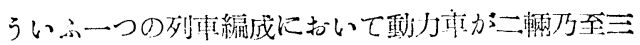
輣ある埸合に集鼠装置をどういふ風にするか，かう

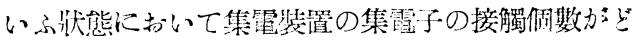
うい心風に火花の繇生に影響して來るか，今極端な

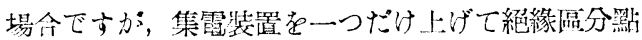
に大つて来る場命について考へますと, 今まてこの

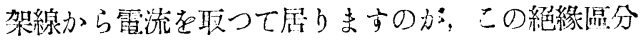

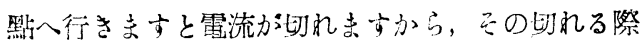
に火花が出る。文これが更に蕉んで絕緣區分點から

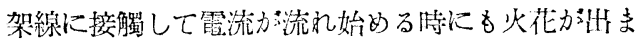

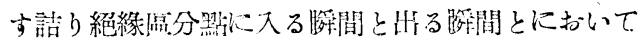

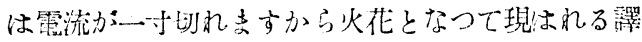
です、所がれ葆し共通甘線の二つの集雪子を使 つて連轉します埸令には前位の方にある集電子力絕 緣温分個所に入つて来ますと前位の集雪子霹流は切 れますけれどを，後位の集溉子小電流を探る。詰り今 まで前と後ろとで共通に電流を探つて居つたのが， 前位り方の負据がななりますから後位の方に轉嫁

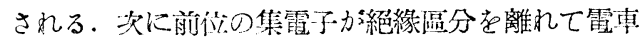
線へ付りばメこれからす電流が流れることになりま

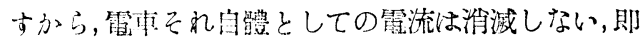

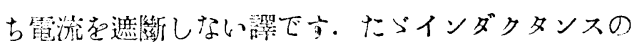

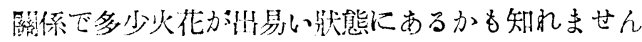

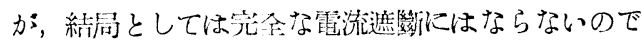
あり古市，從つて一つの集電子を使小場合よりも二

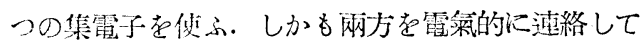
あるならば火花の發生量は少い，所力若しこの連結

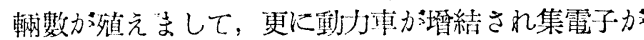
一個使咸されますと，この茎合は集電子としては合 部三つでありますが，前の動力車と後の動力車との 閒泪線で漸絡されてるないとすれ出，これは假令 三つ傎つてをるれぞれみな單事と見做して差支へな

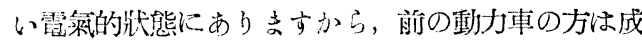


る程火花酸生量は少いかす知れませんが，後の方を

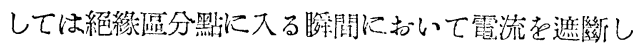
て火花方出る．從てか卓いふ場合は三つ假りに使つ たとしてを全然別々なものとして考へた方がっ.

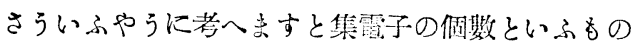
は母線が連絡されてるるならば集露子の數の多い方

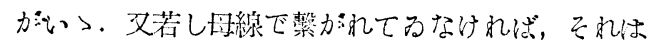

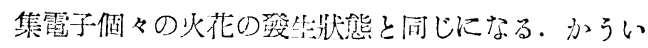
ふやうに考へられます。

それから次に集電子の上に，舟と云つて居ります が，この上に二つの攂板を持たしてるるのが相䓨あ ります。前と後ろの二つが问時に淁觸し，己の二つ

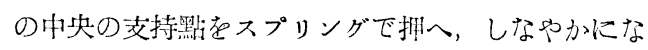
るやうに配置してありますが，さうしますと電流の

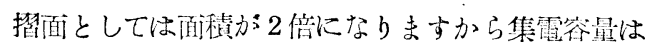
增し，且つ二つ付いてるるからどつちか一つ雪夺線

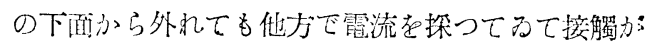
安定であるやうに考へられます。加うい小場合比火 花の登生はどうか，成る程舟としては二つ付いて居

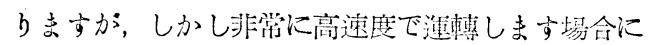

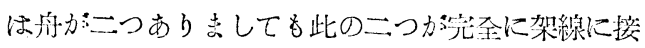
鳋して行かないやうな傾向があります。淮行中には

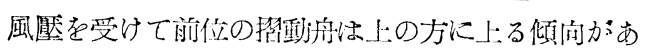

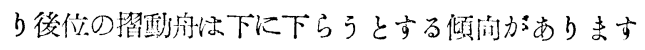
からして, 全體としては電本線に㖶して後方に多少

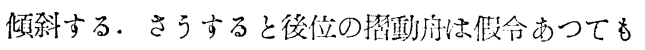
餘り大した役目をしないで前げけで集露してるる。

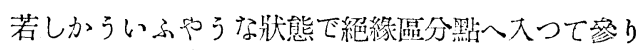
ますとここの舫か二つあつても一つの狀態と同じに

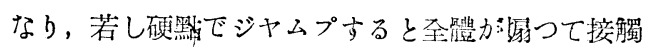
が不完全になるやうに考へられますからして，假令 舟が二つつてをそれ程の效果はしないのではない かこれ私の獨斷的の考へで, 或ひ以間爑つてるる かを知れませんが，一寸そんなやうに感しました。

それから次に集電子の摠板の材料の影響ですが，

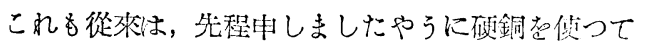
居りましたか，銅資材老節的するとい子見地力ら炭 素が非常に喥了使はれるやうになりました。さうす ると雪車線の銅の磨耗力非常に少い。磨耗防止上非 常に有盆な方法であつて，文時局炕副ふものだと考 へますが，こ礼が花裂生の上にどうい及風な影留 があるか,こ机は先程一寸小さな菑羷での結果とし

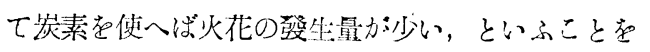

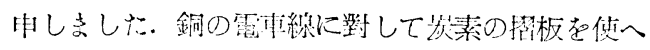

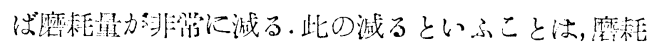

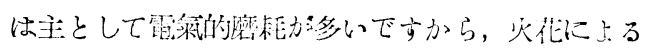

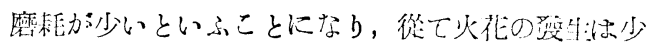
いだらうと，か弓いふやうに获入られ支方。匹方か

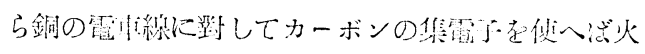

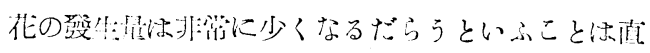

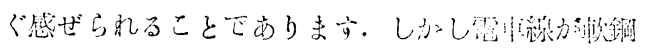

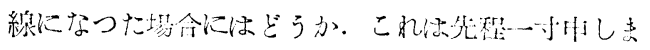

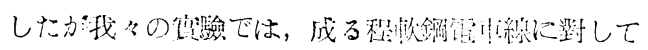

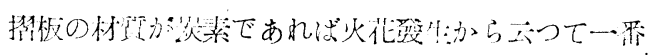

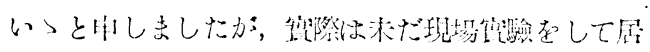

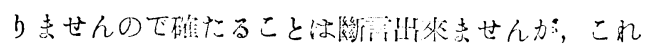

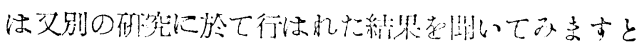

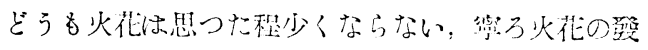

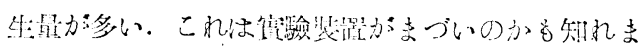

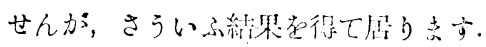

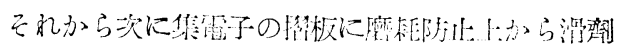

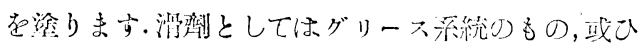

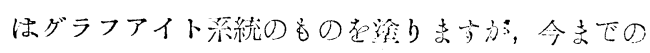

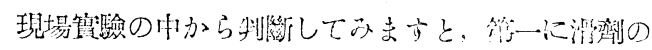
粘度が低いと僅かな火花翟生でもこれに仰ってこの

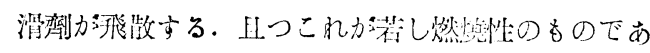

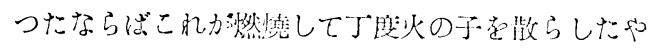

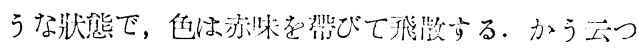
たやうなことが窥へます。しかしこれも抑踰に优つ たのはグリース柔統のものでありましたからかうい ふことになつたのかも矨れるせん. 或ひはグラフア

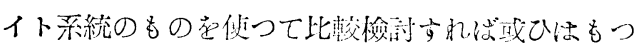

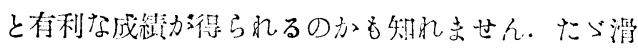

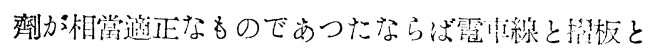

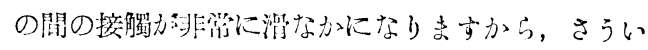
ふ見地加らして火花の磕特が少くなるといふやうに

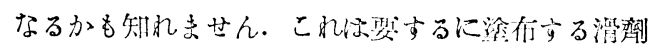

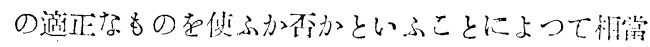

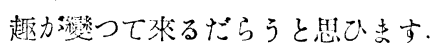

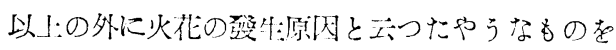

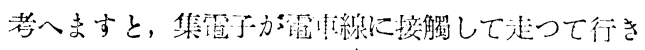

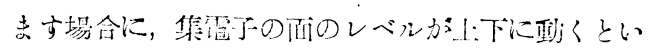

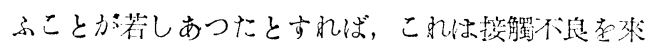

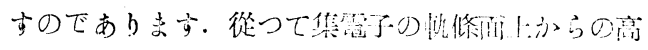

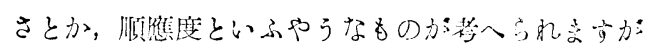

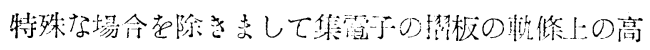


さは省線におきましては標準 5200 粔に定められて

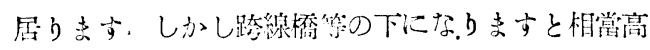
さか限定されまして架總が低くなつてるる關係上，

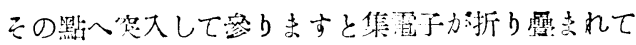

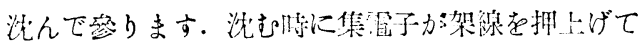
るる力は恰も医力埇した如く作朋しますが，その

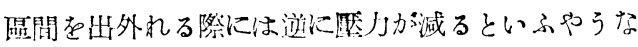

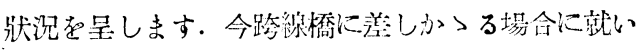

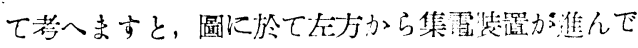
來るものとすれ憍の高さが低いために架緗として

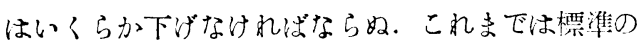
高さであつたが，こつで泿ませる。かう云つた莂合 に此處へ本輛が淮行して參りますと籍電子はだんだ

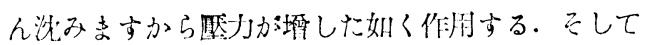
架線の水平部分に達しても降性で架緗加ら離脫して

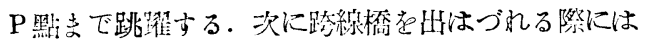

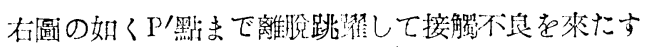
だにこっで火花加出る. 又こうい小哭へ淮大して

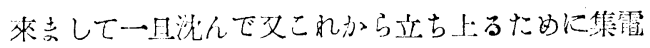

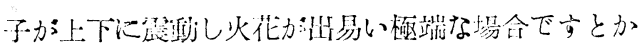

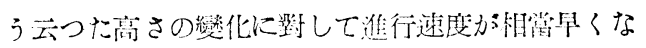

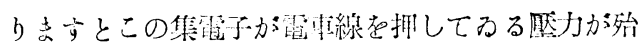

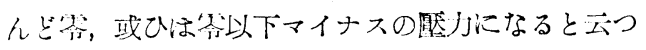

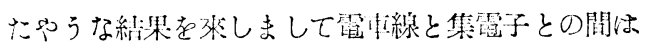

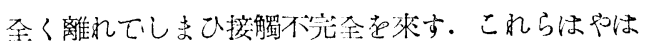
り火花涭生の原因になると思ひます。

\section{集電裝置の離脱跳躍}

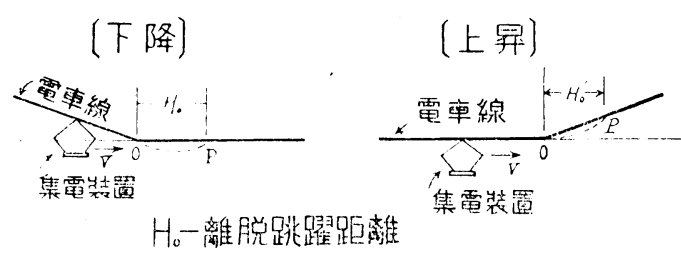

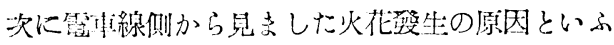

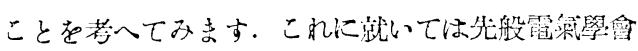

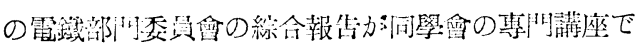
御發表になりましたが.ここで大部倩しくお述べに

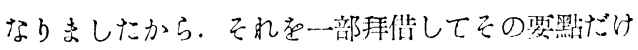
を簡單に御紹介申上げることに敨します。

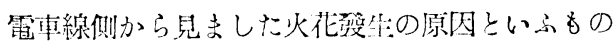

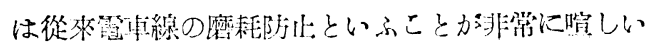

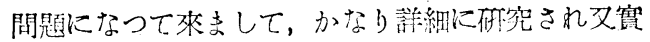

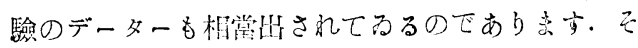

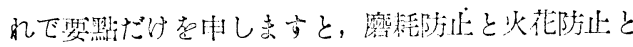

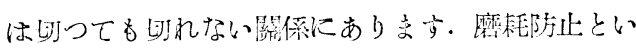
ふことは南ちに，とまでは行を音せんでも，相常火

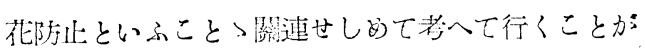
出來るやうに考へられます。先づ架總模造の上から 申しまして，一番火花の出る所はどこかと申します と，これはよく霞驖侧では硬照と云つて居りますか；

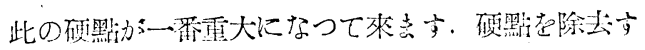

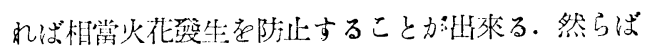
その硬䵞とはどんな所であるか，第一に曲線の所に 架線をカーブ狀に引止める装置か照る。これを曲總 引き装置と云つて居り志すこの曲線引き装罩の所 はどうしてもそれをクランプする装置か㴗りますか ら架總がしなやかでない。詰り硬咱汇なる。

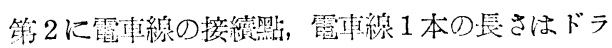
ムの大きさによつてを趡ひますが500米と云つたや うなものが二つのドラムに参かれて居り亲す。これ 慗ざますには從來はダブルイーヤ即ち特殊なイー

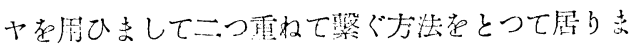

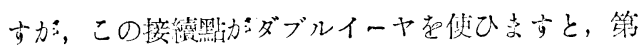

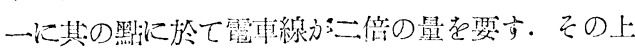

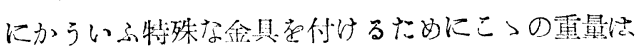
场して來志す、且つこれが折り重なつて居りますか

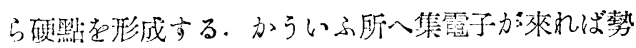
ひしなやかさがありまれんら激笑して火花 を發生し易くなる。これの防止方法としては かういふ㢣驾方をしないだバットジョイント にす礼ばい〉。このバットジョイントの方法 としては銀鑞老使つて接緢する。これは廣島 電鐵璂りで筧施して居られるさうですが，か ういふ方法，或ひは又更にここを電畨愹接す る、最近にはフラッシュバット愹接機を使つ 七熔接を霓柔的に，全く一體のものに作り上 げる.かういふやうな方法をとつてもいいらかよく なる㒛ですが，機戍的强度が落ちて普通の强度の約

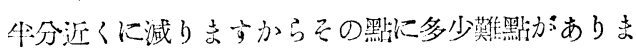
す。しかしかういふ法在とらないで空载接續とい

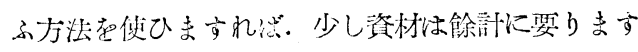
けれどす火花防此の上から空つて非常に效果があり ます，硬點の三番目としましては饋䨵線から電事線

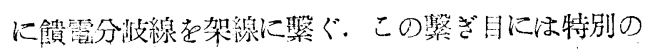


イーヤを要することつ，乏れからこの飭霓分肢線の

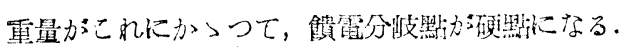
これは饋雪線老直かにこれに慗がないで，途中で多

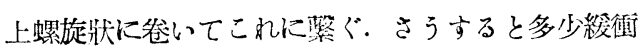
作用をする役目の所方泏來志音からここでしなやか

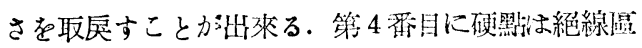
分装置の所であります．先程す火花潩驗として現場 試驗は主に絕緣温分留飞就いて試驗をしたと申しま

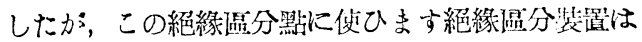
從來木製のもの在使つて居りましたが，その後一部 分得子型のものを使つたすのすありますか，此の木

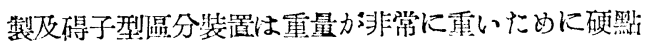

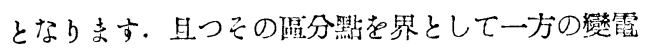
所から饋霞されるすの反對侧の方から瞶電される ものと此處で絕緣されてるるが，この兩侧に多少の 霞位差在生する。さうしますと先程の第溉榬置を二 つ使ふと云つたやうな場合に集電装置が二つですつ て兩侧に跨る.さうしてこれか並列に㟫力㢣がれ て居りますと，かういふ䉓位盖のある所在集霸子を 介して短絡する．その時に集電子の搖值に僅かでは あるが火花を發生するやうなことがありますから， この兩侧の霹值差出出來机ば答に与るやうな方法を とるといくらか緩和されるやうに思ひ去す。第五番 目に旦り線などに使ひ寺すデフレクターといふすの がありますがこれは非常に車いすのでありまして 非常に大きな硬點となります。最近の倾向としまし ては磨耗防止並に火花防止といふ見地加ら，父更に 金屬回收といふ站場から見ましてデフレタターを撤 去しやうといふ氣浬にあります。關西急行篦鐵會社 では逸早くこれを撤去されまして磨耗防止並に火花 防止のために非常に大きな役割をなしたといふこと を聞いて居ります，省におきましてす現在はこれを 殆んど撤去して居ります。たう數ヶ所どうしても除 去することが出來ないといふやうな場所げけ殘し て，現在においてけ㱠んど撤去して居ります。

以上は硬點を主にして考へたるのであり去すか架 線方式の方から云つたらどうか．從來の電軽緗架線 方式におきましては電車線 1 本げけを使つて居るの でありますが，高速度の場合ですと架線 I 本では篦 流容量が足りない，ここで霞車線 2 本を並列に並心 て上からの吊り金具を少しすらしてそれを引トげて わる、複電車線方式と云つて居ります。(これに對し

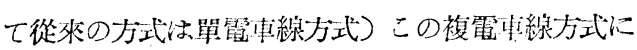

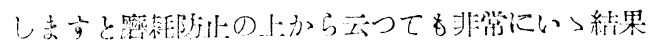

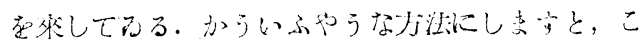

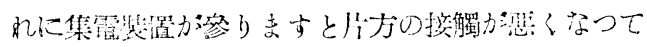

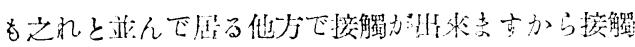

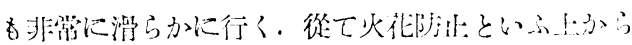

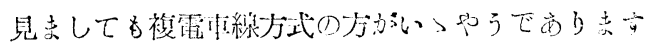

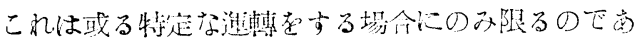

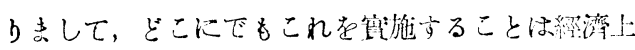

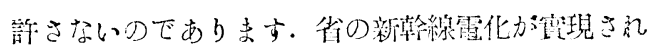

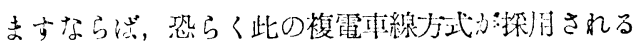
ぜらうと推测して局り去す。

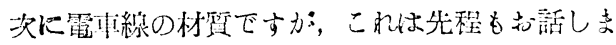

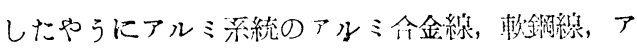

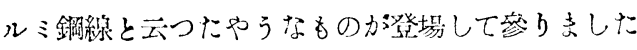

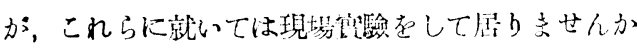

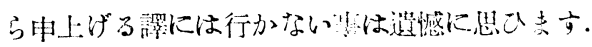

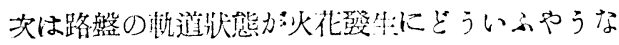

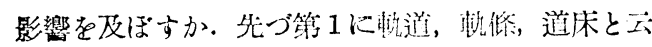
つたやうなものですか，これらの施䜊並に保守方ら

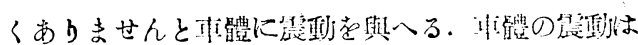

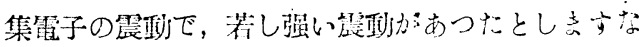

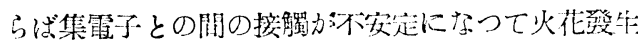

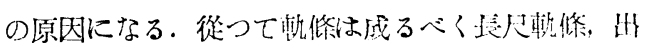

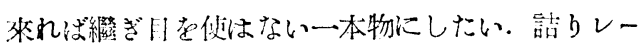
ルとレールを熔按してしまふやうな方法をとり去す

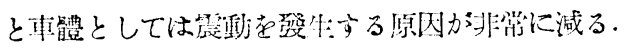

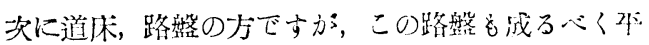

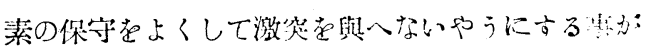
旰要です。

次に橋梁, 踏划りを公つたやうな所记おいては路

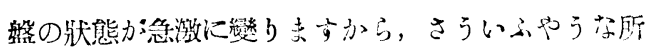

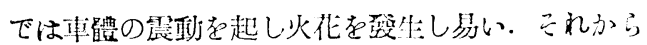
隊道へ大つた所ですか，これは今防空に淔接器倸か；

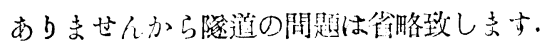

それから線路の曲線とか公蓜と云つたやうなすの

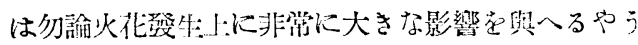

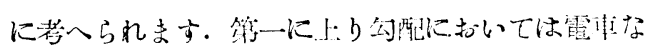

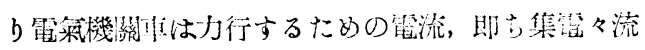
が多いですから，集雷々流の多いといふことは火花

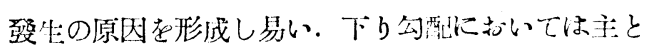

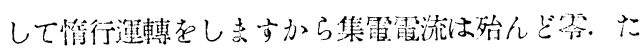

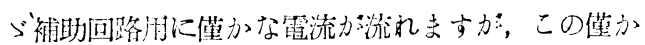
な電流において著しスパークが起るとすれ出别問題 
ですが，一番主たる原因の主集霞々流がありません

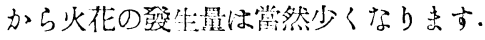

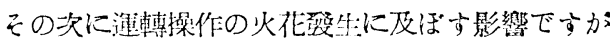
第 1 に加速方る時，詰り起動筞の埸合ですが，この

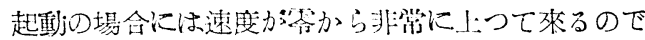
すから速度としては非常に低い瀷だす。かう云つた

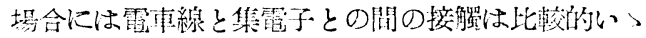

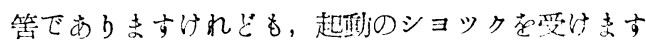
からやはり接解は多少不筞全且つ不灾题になり膯与

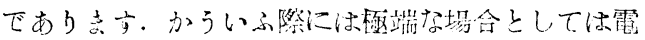
弧在要绖し支す。

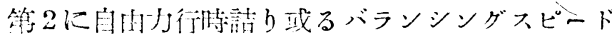

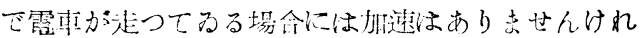

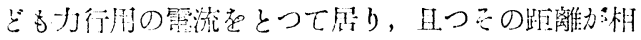

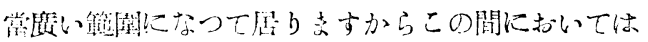

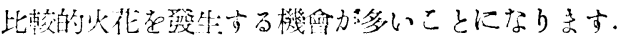

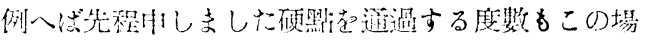
命には此較的多いといふことが芬へられます。

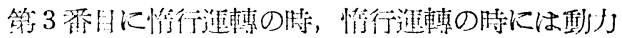

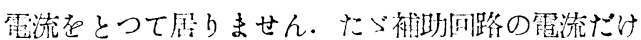

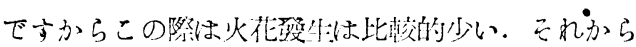

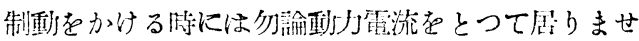
んからスパークは起らんと考へてい〉摆です。麗力

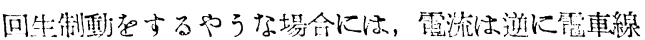
の方に參りますから集電子と雪車緗の間に雷流が流 れる.從つてかうい小やうな制動を行ひます場命に は火花登生は多少趣㕝罚にして參ります。一般の制 動洔に於いては殆んど火花は起らないと考へてもい 〉と思ひます。

第 5 番目に集電々流の大きさですが，これは先程 も一寸由」:げましたやうに集電々流力゙大きい程火花

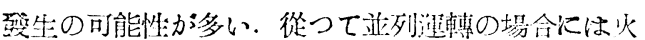

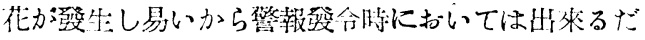

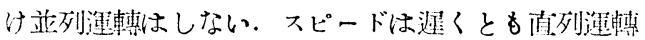

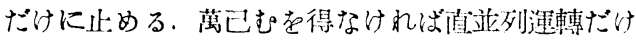
に止めてるれから先は淮めない。汃ういふやうなう

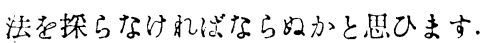

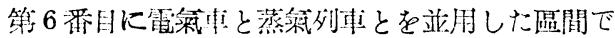

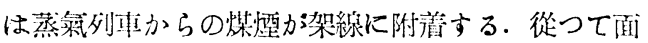
が污れて居つて火花起登生し易い。

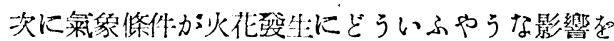
及汪すか。第1に外氣の溫度ですが，これは夏と然 と較べすれば夏の方は架線力膨脹して仰び，從つ

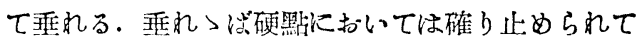
るるしその途中においては多少垂れ下る爭味があり ますので勧霓子と雪事線との閒の接觸力㳅安定, 且 つ不完全になり易いといふことが想像されます。綪 局火花發等:老促進せしむる倾向にある.

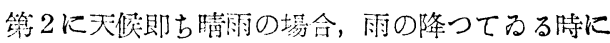

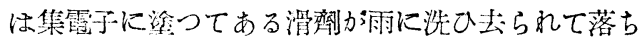
折角㧡触草よくしやうとしたすのが洗ひ去られます ために火花湓生が多くなるであらうと考へられます 筕 3 番目に降雪の影響ですか;，普通の狀態であれ ば大した影留はないかを知れませんが，非常に寒冷

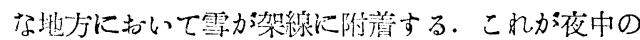

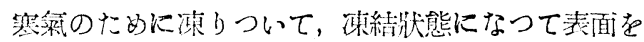

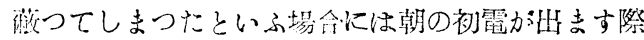
にこの水を破つて集電々流方通らなけれ待ならぬ。

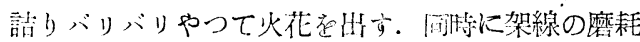

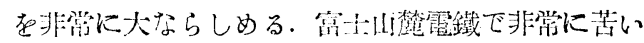

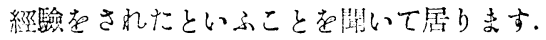

大部時開を食ひましたやうですから，後ははしよ つて結鍮に入りたいと思ひます。

火花防止の方法ですが，以上㓞しましたやうなこ と老綜合して見末するなら㳻自らどういふ風な方面

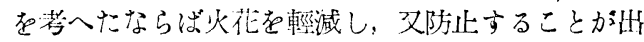
來るだらうかといふことが多少制るのではないかと 思ひます，從つてその具娟的な方法についてはこ〉 に改めて申上げますことを省略致させて頂きまして 、最後に今後，これ汃らかういふ方面の硏究を進めて 行く」ににおまして，贔際現場において登生する火 化，或ひは雷流を測定する方法の種類と申します か，分類を少し考へて見ることに致します。立れを 列擧しますと次の如くなります。

\section{霞車線集露子閒の火花測定法}

\section{1. 梘覺欟测}

$$
\begin{aligned}
& \text { イ. 地上:よりの目測 } \\
& \text { 口. 車中上りの目测 }
\end{aligned}
$$

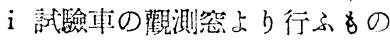

$$
\begin{aligned}
& \text { ii 鏡党利用古るの }
\end{aligned}
$$

\section{2. 宾嘪撮影}
イ、晋通の傁冥機を使用するもの
口. 䯩速度活動竄具撮影機芭使用方るるの

3. 集電々流をオシログラフにて撮影

4. 光霞管纪て光度測定 


\section{イ、部錄計器を使用するもの \\ ロ.オシロダラフにて撮䅟するもの}

先づ第1に先程申しましたやうな現場惯駼にあい

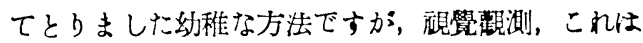
㱠んど定量的とは申されませんて，たく出るか出な いか，場合に上つては番躆に上つて多少大中小位の 判別をする. から云つたやうな極く奻稚な方法, こ

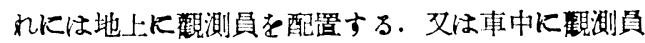
を置く、それからこの車の中に居ります䤄测員は，

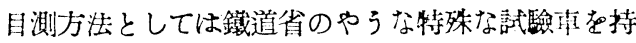
つて居ります場合には試験車に覞測空かありますか

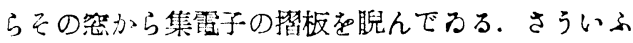
ことが出來ますが，さうでない場合には鏡を俅へば い〉と思ひます。これは車の空外侧に箱却作りまし て途中に二禹鏡面置きまして車內で映像が見光る やうにする。

第 2 は䈍買撮影，それには普通の具棋機を使ふの

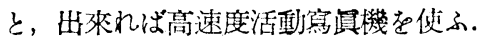

3 番目はこれは間接法ですか，集霓々流をオシ ログラフで觀測する。

4 番目が光霹管で光度を測る。るれにを大體二つ に分れまして記錄㰻器で描かせる方法と，てれから 光霞管の電流をオシログラフに入れる，大體現在ま でこんなやうな方法が考へられるのではないかと思 ふのであります。

第1の方法は，これはなら㼛覺で見るだけですか ら害際技衡者としての測定方法としては問題になら ないと思ひます。たつ適當な部器かるない時代には己 むを得すかういふやうな方法を探つたのでありま †.

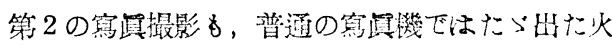

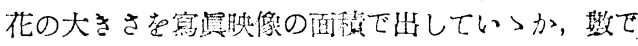

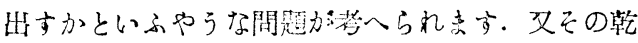
板，又はフイルムの檑類にも蹬係するぜらうし，現

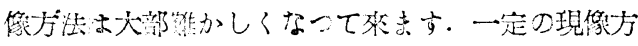

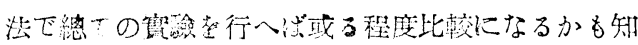

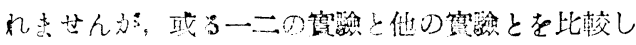

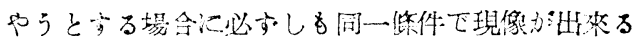

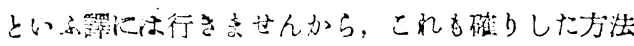
ではないと思ひ京す。

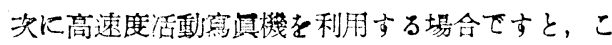

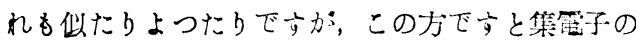

電車線に對する相對關係を時間的に見てどういふや うなモーションをするかといふこと都分析する資料 を提供しますからこれ相相いう方法だらうと思ひ

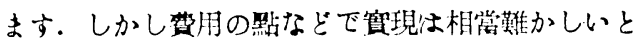
思ひます。

第 3 番目に集雪々流をオシログラフで撮るといふ のは，オシログラフさへ利朋すれば出來る方法です かー一しかしこれは間接法ですから，㨁接測定する

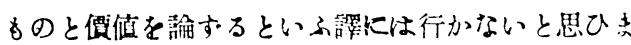
$+5$

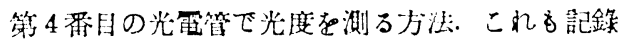
計器を使ひますと部器のエナーシヤーがありますか ら忠慨に光りの且に柋して速恶させて測るといふこ

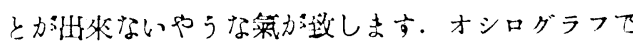
あるなら络国有振動周期力短いるのですから速㡖し 得るやうに考へられます。結局機诚このるのは光管 管を优つてオシログラフに入れて测り，火花经生:の メカニズムは高速度活抄密具機を作用してやる。な

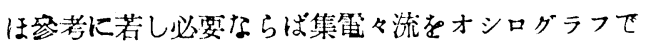
撮る。この三つを合せて色々な研究に利用したら理 想影でないかと思つて居ります。私共としても現場

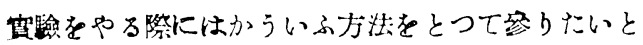

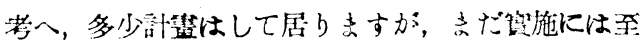

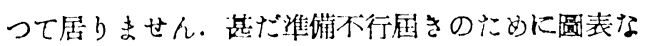
どを利用してお話することか出來志せんで越で申翋 ありませんでした。これで私のお話は終ることに致 しょす。な部時撮りましたオシログラムもありま

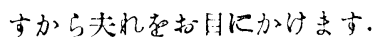

\section{（以下颜涂）}

(筫間)一寸何ひたいでるか，经留になり去した ら整車は期くのですか。どうですか。

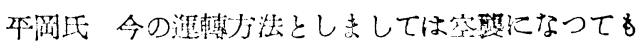

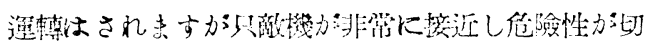

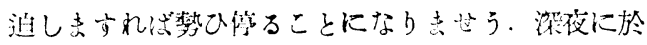

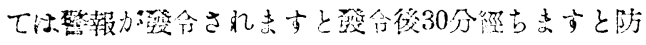

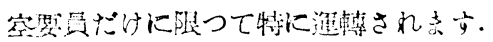

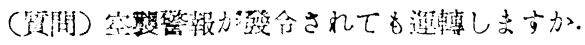

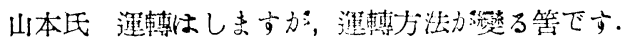

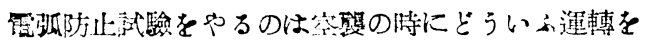

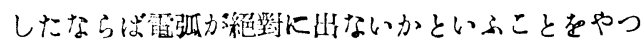




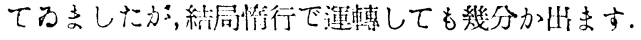
しかしこの瑟度か非笛に微々たるすのでありますか

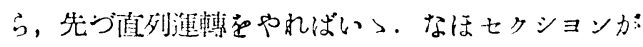

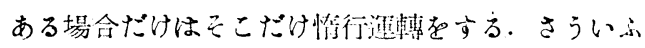
やうな教へだもつて，速度は非密に溚ち劣すけれど

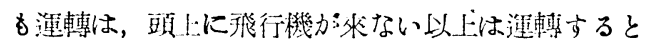
いふ建前になつて居ります，從つてここでダィけが すつかり下る譯です。

(質間) 市電はどうですか. 沼倉氏 今の所は運䡼しない方䣄です。 山本氏こつで注時しなければなりませんのは列檕 運轉は致し去すけれどす，巨の列戈の大部分は背物 列車であるといふことになるのではないかと思ひま

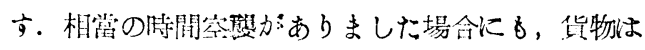

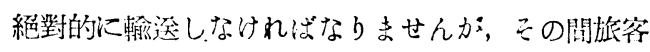
は一時中止される芬合があるのではないわと思ひま †.

(質問) 筫際間題として火化は本畄に困ることに なるか，今の所先全に浙法か出來ない㭊態ですか 山本氏 さうです。

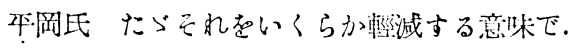

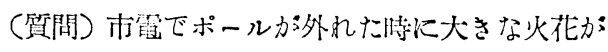
出るが，あの明るさはどの位ですか。.
测倉氏 100 㷎光以上

(質閒) あの位の距離にあれ位，東䒚全體として

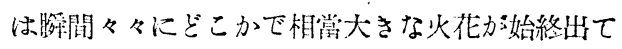
るる譯ですね。.

沼会比さうです。

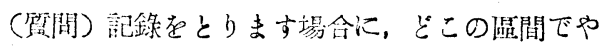
つたといふやうなこと都錄する方法はあります j).

山本氏 省と致しましては試驗草がありまして, 試 驗具で參考のために列車速度をとります. 列事速度 以外にどこを通過したとか，ノチの位置，上り勾

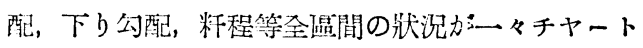
に現はれるやうにはつて居りますからあとで見較心゙ て考察か泏來るやうになつて居ります。

(貿間) 高さの影留のことがありましたが，電車 線か下つて來た，又上つて來た，さういふやうな 場合をスパークするが，勾配文適虽にやればいく らか輕減されるやうな率がしますか。

平岡氏 雷車線に勾配があつて。其の戀化が餘り甚 けしくなければスパークに大して影響がありません

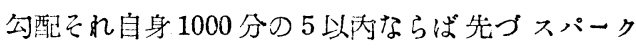
に影響はありません。

\section{火花寫具

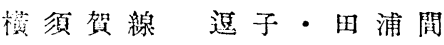 \\ 琶军“棪關菆 E F 10 形 \\ 㹸甲形絕螕區分個所通過時 \\ 集需子押上力 $6.0 \mathrm{~kg}$}

$\begin{array}{ll}\text { 速 度 } & 30.5 \mathrm{~km} / \mathrm{h} \text { (值並列ノッチ) } \\ \text { 集電々流 } & 220 \mathrm{~A} \\ \text { 火花程度 } & \text { 大 }\end{array}$
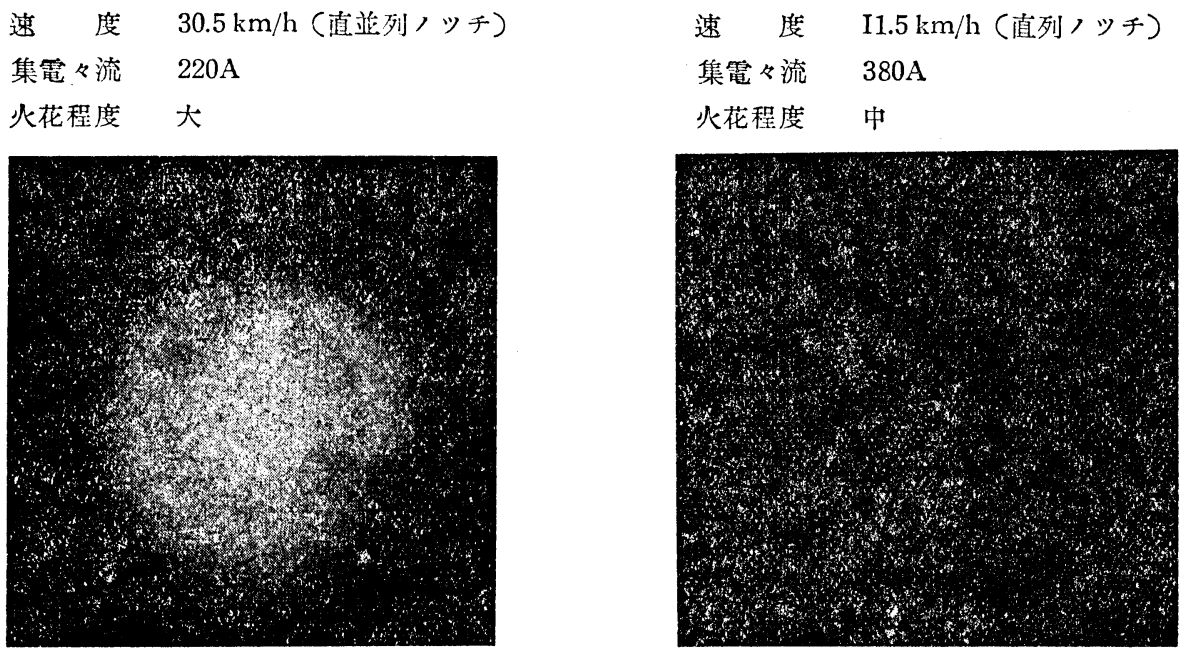


$$
\text { オシログラム }(\text { No.1) 集 霓を流 }
$$

電策譏關車 EF10形

樌 須 賀 線 造子・田浦間

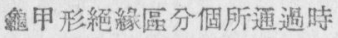

速度 $11.5 \mathrm{~km} / \mathrm{h}$ (直列フツチ)

集電子押上力 $6.0 \mathrm{~kg}$

斯電》流 $380 \mathrm{~A}$

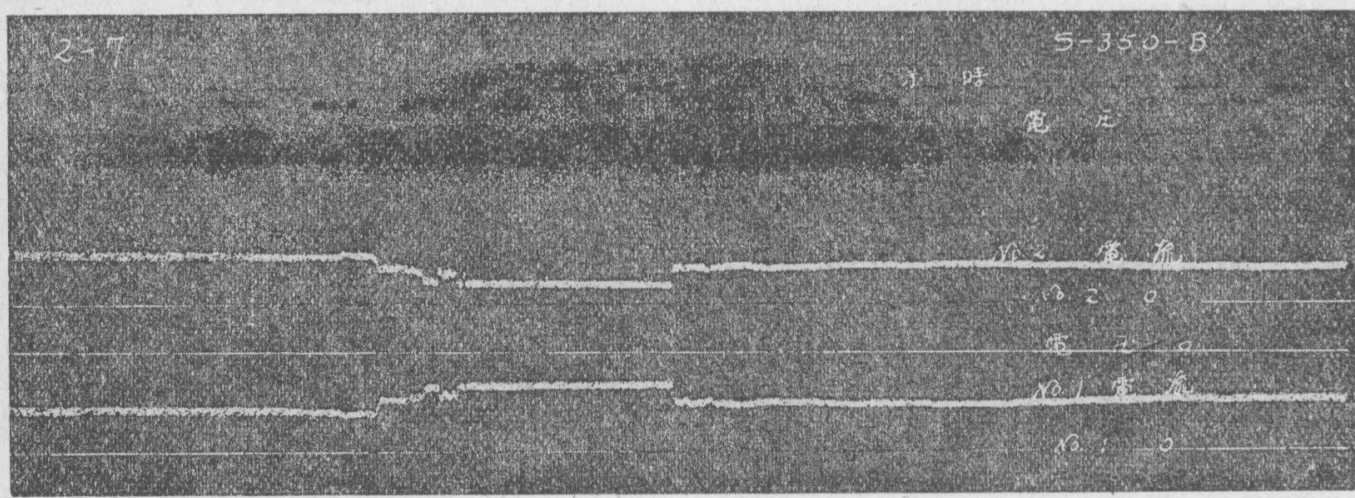

オシログラム(No.2) 集電々流及火花光度

電氮機關車

E F 1 ? 0 形

昭和 16 年 8 月試騟

東 海道 線 沼津・新鶴見間

小”田原出口空氣絕螕區分個所 $8.6 \%$ 上り勾配

速 度 $28 \mathrm{~km} / \mathrm{h}$ (值並列ノッチ)

集電子押上力 $6.0 \mathrm{~kg}$

集電\&流 $430 \mathrm{~A}$
昭和 16 年 8 月試铪

火花程度 中 